\title{
Are Teachers in Africa Poorly Paid? Evidence from 15 Countries
}

\section{David K. Evans, Fei Yuan, and Deon Filmer ${ }^{\dagger}$}

\begin{abstract}
Pay levels for public sector workers_-and especially teachers — are a constant source of controversy. In many countries in Sub-Saharan Africa, protests and strikes suggest that pay is low, while simple comparisons to average national income per capita suggest that it is high. This study presents data on teacher pay from 15 African countries, along with five comparator countries from other regions. The results suggest that in several (seven) countries, teachers' monthly salaries are lower than other formal sector workers with comparable levels of education and experience. However, in all of those countries, teachers report working significantly fewer hours than other workers, so that their hourly wage is higher. Teachers who report fewer hours are no more likely to report holding a second job, although teachers overall are nearly two times more likely to hold a second job than other workers. With higher national incomes, the absolute value of teacher salaries rises, but they fall as a percentage of income per capita. The study explores variation across types of teacher contracts, the association between teacher pay and student performance, and the association between teacher pay premia and other aspects of economies.
\end{abstract}

† The order of author names was randomly assigned using the American Economic Association's author randomization tool.

Keywords: Education; teachers; public sector; teacher pay

JEL: I20; I25; J31; O12

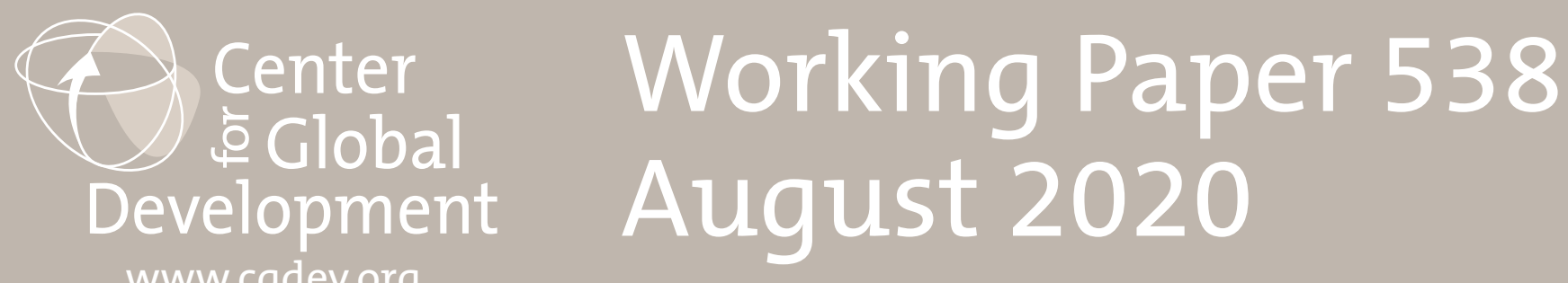




\title{
Are Teachers in Africa Poorly Paid? Evidence from 15 Countries
}

\author{
David K. Evans \\ Center for Global Development \\ devans@cgdev.org
}

Fei Yuan

Harvard Graduate School of Education

fyuan@g.harvard.edu

Deon Filmer

World Bank

dfilmer@worldbank.org

The order of author names was randomly assigned using the American Economic Association's author randomization tool.

Lawrence Katz, Owen Ozier, Halsey Rogers, Pieter Serneels, John Tebes, Francis Teal, and Martin West provided helpful comments. Amina Mendez Acosta provided research assistance.

The findings, interpretations, and conclusions expressed in this paper are entirely those of the authors. They do not necessarily represent the views of the World Bank or the Center for Global Development and their affiliated organizations, or those of the Executive Directors of the World Bank or the governments they represent.

The authors thank the Bill \& Melinda Gates Foundation, and the Knowledge for Change program, for financial support.

David K. Evans, Fei Yuan, and Deon Filmer, 2020. "Are Teachers in Africa Poorly Paid? Evidence from 15 Countries.” CGD Working Paper 538. Washington, DC: Center for Global Development. https://www.cgdev.org/publication/are-teachers-africa-poorlypaid-evidence-15-countries.

Center for Global Development 2055 L Street NW Washington, DC 20036

202.416.4000

(f) 202.416 .4050

www.cgdev.org
The Center for Global Development works to reduce global poverty and improve lives through innovative economic research that drives better policy and practice by the world's top decision makers. Use and dissemination of this Working Paper is encouraged; however, reproduced copies may not be used for commercial purposes. Further usage is permitted under the terms of the Creative Commons License.

The views expressed in CGD Working Papers are those of the authors and should not be attributed to the board of directors, funders of the Center for Global Development, or the authors' respective organizations. 


\section{Contents}

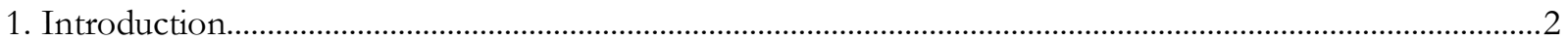

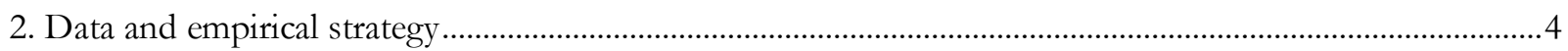

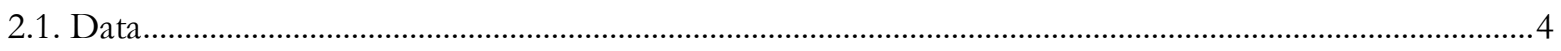

2.2. Empirical strategy for estimating relative earnings................................................................................

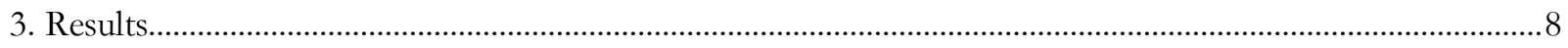

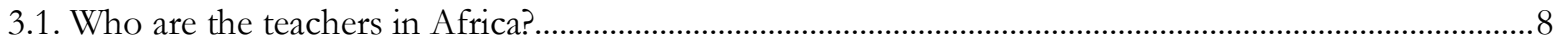

3.2. How has the supply of teachers changed over time? ................................................................................. 9

3.3. What do teachers and other workers earn in Africa? .........................................................................

3.4. How are teachers paid relative to other professionals, adjusting for controls? .....................................11

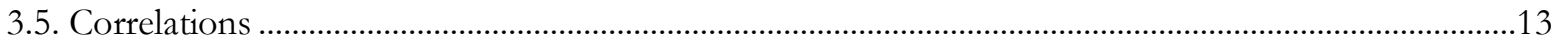

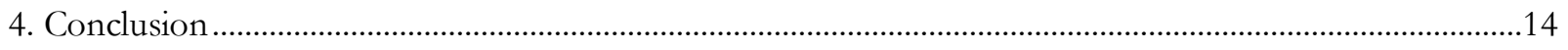

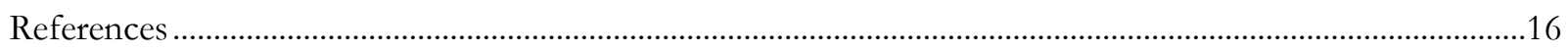

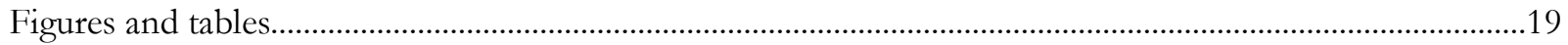

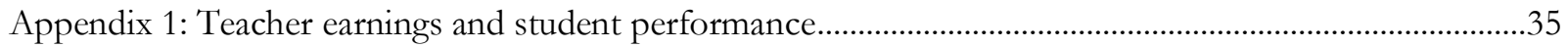

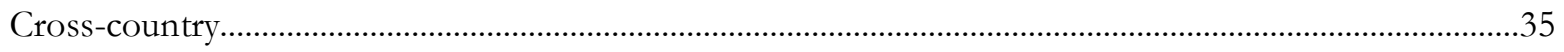

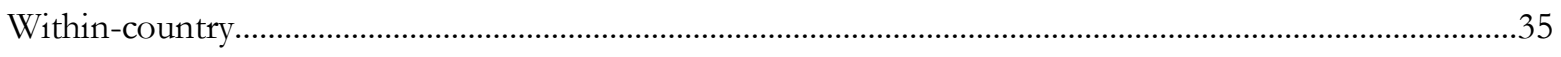

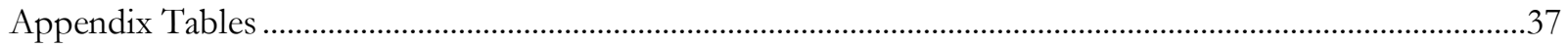




\section{Introduction}

Determining the right level and structure for public sector salaries is a challenge in all countries. Nowhere is this more salient than among teachers. The last few years have seen unprecedented numbers of teacher strikes across the United States (Blanc, 2019), and salary has been at the center of demands in almost every case. But this is a global phenomenon, with teachers striking in Mexico, Argentina, India, Uganda, and Mozambique. ${ }^{1}$ Evidence on the efficacy of raising teacher salaries is mixed, with cross-country work showing that countries with higher teacher salaries tend to have higher student learning outcomes but individual country experiences showing little impact of blanket raises in teacher pay (Hanushek, Piopiunik, and Wiederhold, 2019; de Ree et al., 2018). The question consistently arises: Are teachers poorly paid?2

In Africa, this challenge is particularly salient. In order to achieve universal primary and secondary education, Sub-Saharan African countries are predicted to need 17 million additional teachers (UNESCO 2016). The quality of the incoming teachers will significantly affect the educational outcomes of children in African countries, as teacher quality is a critical determinant of students' test scores, non-test score behaviors, and long-term outcomes (Araujo, Carneiro, Cruz-Aguayo, \& Schady, 2016; Chetty, Friedman, \& Rockoff, 2014; Hanushek \& Rivkin, 2010; Jackson, 2012). Furthermore, these teachers will join education systems characterized by poor performance (Bold et al. 2018). Thus, how to attract, retain, and motivate high-quality teachers in order to deliver quality education has been an ongoing debate among African policy makers. Teacher pay is a key ingredient to that process.

The challenge is compounded by the fact that there is limited documentation of this policy-relevant topic in Sub-Saharan Africa, in part because there are no systematic teacher salary data across African countries. UNESCO occasionally documents teacher salaries in terms of country GDP per capita, but it does not provide information on relative wage differentials. ${ }^{3}$ Without that information, setting teacher salaries to attract the desired candidates is difficult.

In this study, we assemble data from representative population or labor force surveys across 15 African nations and five comparator nations in other regions. We compare salaries for teachers to other wage workers of similar age, education, rural/urban sector, and gender. We then explore structural factors that may explain teacher wage differentials. ${ }^{4}$

Our analysis demonstrates that, across countries, teacher salaries rise in absolute terms with GDP per capita but that they fall as a percentage of GDP per capita - i.e., they rise more slowly than GDP per capita. Within countries, we find that in nine out of 15 countries, teachers' monthly salary is lower than that of other comparable wage workers; the difference is statistically significant in seven of the 15 countries. In five countries (Burkina Faso, Côte d'Ivoire, Namibia, Senegal and Zambia) teachers' monthly salaries are higher

\footnotetext{
${ }^{1}$ See reporting on Mexico (Mexico News Daily, 2019), Argentina (Reuters, 2019), India (Kumar and Kumar, 2019), Uganda (Ahimbisibwe, 2019), and Mozambique (da Conceição, 2017).

${ }^{2}$ A question that is separate from the level of teacher salaries but equally important is the structure of teacher salaries. A range of recent work explores different teacher and other public sector pay structures in low- and middle-income countries (Barrera-Osorio and Raju, 2017; Cilliers et al., 2018; Gilligan et al. 2019; Leaver et al., 2019; Mbiti et al., 2019; Muralidharan and Sundararaman, 2011).

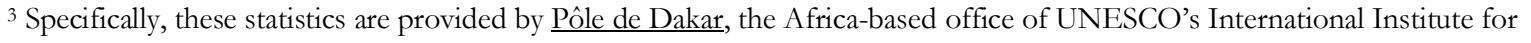
Educational Planning.

4 While these are more formally reported earnings, we refer to them as salaries and wages for simplicity.
} 
than comparable workers. But simple salary comparisons are complicated by adjustments for working hours. In five of the nine countries where teachers' monthly salaries are lower and where teachers report their hours, their hourly wage is higher than that of other workers. Positive premia tend to be higher for teachers on permanent contracts - who get paid more but work similar hours - than for teachers on fixed-term contracts. Teacher earnings are not more determined by age and education than those of other workers. The fraction of teachers in the workforce has also risen across countries over the last two decades. Contrary to expectations, the teacher wage differential (monthly or hourly) across countries is not associated with GDP per capita, the size of the formal sector, the share of female workers in other wage jobs, the rate of unionization, or female labor force participation. We find a positive association between teacher pay differentials and student learning outcomes, both using cross-country and within-country data, although we cannot rule out non-causal explanations for this.

This analysis contributes to three literatures. The first examines the role of salary in attracting quality candidates to the public sector. Ferraz and Finan (2011) document that higher wages for politicians improve political performance in Brazil. In addition, Dal Bó, Finan, and Rossi (2013) find that when salaries increased, more able applicants applied for public-sector jobs. With respect to teachers, combining cross-country data on teacher salary and student performance on international assessments in OECD countries, Dolton, Marcenaro-Gutierrez, Pistaferri, and Algan (2011) suggest that "the relative wage of teachers is a very good proxy for their average quality." Recently, Hanushek et al. (2019) show that in OECD countries, teacher salary premiums are associated with teacher cognitive skills and student performance. Our results are consistent with those of these studies and contribute to the literature by adding evidence from African countries.

The second examines the role of teacher pay changes on student learning. When Indonesia substantially increased teacher pay, teachers' job satisfaction rose but student academic achievement did not (de Ree et al., 2018). Several studies examine the effect of providing hardship allowance to teachers working in remote areas in developing countries on student performance, and all of them find little to no effect (Cabrera and Webbink, 2018; Bau and Das, 2017; Pugatch and Schroeder, 2018; da Silva Filho and de Xavier Pinto, 2014). By contrast, we find a positive association between teacher wage premium across countries and student performance. However, the findings might not be contradictory to each other if we consider the potential mechanisms for how student learning might be affected. The literature on teacher pay changes measures the short-term effects of such policies, and the primary mechanism to improve student learning in that time frame is the effort of teachers in the current system. On the other hand, the mechanism associated with wage differentials is more likely to be workers' self-selection. When teacher pay is doubled, it may take years to hire new teachers and improve the overall quality of the teaching force. However, de Ree et al. (2018) make the argument that because the total supply of teachers turns over slowly, paying current teachers much more in the hopes of slowly achieving a more effective body of teachers may not be a cost-effective education investment.

The third explores cross-country differences in teacher salaries and their association with other outcomes. Finan, Olken and Pande (2017) document that low-income countries provide higher wage premiums to public sector employees. Mizala and Ñopo (2016) conduct an analysis of teacher relative pay using data from 13 Latin American countries and find that teachers earn less than "other professionals and technicians" with similar observable characteristics. Our analysis on low- and middle-income countries in Africa also finds 
higher salary premiums in lower-income countries but we also observe substantial variation in teacher salary premiums given the income level. 5

The rest of this paper is structured as follows: Section 2 describes the data and empirical strategy. Section 3 describes our results. Section 4 discusses and concludes.

\section{Data and empirical strategy}

\subsection{Data}

We draw on several sources of data. Our principal analysis of teachers and their salaries builds on household surveys and labor force surveys conducted in 15 low- and middle-income countries in Sub-Saharan Africa (Table 1 Panel A). ${ }^{6}$ We chose these countries and surveys based on three criteria:

1. The surveys included detailed information on occupation, working hours, earnings, educational attainment and other basic demographic characteristics of surveyed household members or individuals.

2. The surveys were conducted no earlier than 2010. If there were multiple surveys available for the same country, we chose the most recent one.

3. The survey data were accessible.

The resulting set of countries included Côte d'Ivoire, Namibia, Sierra Leone, Tanzania and Zambia with data from national labor force surveys; Burkina Faso, Malawi, Niger, Nigeria and Uganda with data from Living Standards Measurement Surveys (LSMS) with an employment module; and the Democratic Republic of Congo, The Gambia, Ghana, Liberia and Senegal with data from national household surveys with a labor force module. We added five middle-income countries from East Asia (Cambodia and Indonesia), Southeast Asia (Pakistan) and Latin America (Bolivia and Mexico) as comparison countries (Table 1 Panel B). We selected these countries among a set for which data were accessible to us, in order to cover a range of income levels comparable to those across the Sub-Saharan African ones. In total, we gathered survey data from 20 low- and middle-income countries. Table 1 provides background information on these surveys: the countries, the source of the survey data and the year in which the survey was conducted.

The focus of our analysis is primary and secondary school teachers. This choice was driven by the fact that teachers in the basic education cycle make up the bulk of the teaching workforce. Additionally, their salaries are often set centrally and drawn directly from the government expenditure on education, which makes crosscountry comparison possible and meaningful. From each of these surveys, we identified primary and secondary teachers using occupation codes listed in interviewer manuals. Most of the surveys used the International Standard Classification of Occupations (ISCO) or a variant form of it. The occupation codes allowed us to differentiate primary and secondary teachers from other educators such as pre-primary teachers, special education teachers, and university lectures and professors. Exceptions are Malawi where the data classifies teachers at all levels in the same group, and Pakistan where pre-primary and primary teachers are

\footnotetext{
5 One recent report examines teacher pay across 13 countries in Sub-Saharan Africa and finds that primary school teachers are underpaid by the hour, compared to other professionals, and secondary school teachers are comparably paid. However, the analysis is pooled for the 13 countries, with no indication of country-by-country variation (see Bashir et al. 2018, Figure 4.7). 6 We use the World Bank 2019-2020 income and regional classifications (World Bank, 2019b).
} 
grouped. (Detailed data processing notes can be found in Appendix Table A1.) We retained these two countries in our analysis, but our conclusions are similar if we exclude Malawi and Pakistan. We excluded educators other than primary and secondary teachers from our analytical samples since their jobs and pay determination may be quite different from primary and secondary teachers. Throughout this paper, "teachers" therefore only refers to primary and secondary school teachers.

Table 1 gives details about our samples: the number of teachers, the share of teachers in the formal sector, and the shares of teachers in the overall workforce in each survey. The number of teachers sampled in the African countries ranges from 119 teachers in Niger to 1,104 teachers in the Democratic Republic of Congo, with 370 teachers on average per country. The sample sizes in the comparator countries are larger: from 393 in Cambodia to 12,077 in Indonesia. On average, African teachers represent 2.2\% of the overall labor force in each survey, which is similar to that in the comparator countries $(2.4 \%) .^{7}$ This share is also comparable to that in high-income countries like the United States, where primary and secondary teachers make up about 2.2\% of the labor force. ${ }^{8}$ On the other hand, African teachers on average constitute a larger share (13\%) of wage employment in each survey than the teachers in the comparator countries $(8 \%) .{ }^{9}$ Because the share of teachers in the labor force is similar across these two samples, the higher share of wage employment in the African sample is likely due to the fact that the number of wage jobs in African countries is smaller.

We also include supplementary analysis using data from a student test in grades 2 and 6 and a complementary teacher survey administered to francophone African countries in 2014, the PASEC (PASEC, 2015). ${ }^{10}$ We include data from all available countries: Benin, Burkina Faso, Burundi, Cameroon, the Democratic Republic of Congo, Côte d'Ivoire, Niger, Senegal, Chad, and Togo. Finally, we present data on the total numbers of teachers and students from the UNESCO Institute for Statistics (UNESCO, 2020) and data on the labor force across countries from the International Labour Organization (ILO, 2020).

\subsection{Empirical strategy for estimating relative earnings}

Traditional models of wage determination assume some relationship between earnings and productivity. The simplest of these models is that proposed by Mincer (1974), which relates earnings to basic proxies of human capital such as education and age or experience. Public sector wages, and in particular those of teachers, might be driven by these factors but also by other factors such as achieving social goals, by rigidities introduced as a result of collective bargaining, or by other bureaucratic or institutional factors (e.g., patronage or nepotism) (Finan, Olken, and Pande, 2017).

Simply presenting descriptive statistics—stratified by certain characteristics—can shed light on general patterns but may not capture systematic differences associated with occupations. For example, there might be different job requirements for teachers, and observed differentials may pick up the effects of age or experience. Additionally, there may be regional differences; for instance, urban or rural residence might be

\footnotetext{
7 The labor force is defined as people aged between 15 and 64 who worked, looked for a job in the past week, or had a job to return to.

8 The statistic of $2.2 \%$ for the US is derived from the May 2018 National Occupational Employment and Wage Estimates reported by the U.S. Bureau of Labor Statistics. It is the share of all employment that is categorized as having the occupations of "Elementary and Middle School Teachers" or "Secondary School Teachers."

${ }^{9}$ Formal sector employees are people in the labor force who reported they earned a wage or salary in their primary jobs.

10 PASEC stands for Programme d'analyse des systèmes éducatifs de la Confemen.
} 
systematically related to both earnings as well as the probability of being a teacher. Thus, in this analysis, besides providing descriptive statistics of teachers and their compensations, we conduct a set of multivariate analyses to examine teacher earnings differentials. Specifically, we estimate models that control for the basic productivity factors (following Gregory and Borland 1999), as well as other potential confounders-namely gender and urban/rural residence - that might differ systematically between teachers and comparable wage workers.

We use the specification in Equation (1) to run a set of multivariate regressions that control for potentially confounding effects and attempt to isolate the association between earnings and being a teacher. To account for potential biases associated with wage distributions of different occupations (i.e., the distribution of teacher earnings is more compressed), we fit Equation (1) using both OLS and median regressions.

$$
\ln \left(\text { Earning }_{i}\right)=\gamma_{0}+\gamma_{1} \text { Teacher }_{i}+\gamma_{2} \text { Post_secondary }_{i}+\gamma_{3} \text { Age }_{i}+\gamma_{4} \text { Age }_{i}^{2}+\gamma_{5} \text { Male }_{i}+\gamma_{6} \text { Urban }_{i}+\varepsilon_{i}(1)
$$

where $\ln$ (Earning) is the log of total reported earnings (monthly or hourly, depending on the specification), Teacher is an indicator variable for teachers, Post-secondary is an indicator for having post-secondary education (and the regression sample is limited to wage workers with secondary or post-secondary education), Age is the individual's age, Male is an indicator for male individuals, and Urban is an indicator for urban residents.

Despite the fact that several potentially confounding observed variables are controlled for, the estimated coefficient may still not represent the isolated impact of being a teacher on earnings, as there may be unobserved factors that affect both earnings and the probability of being teacher. If this is the case, the coefficient on the teacher variable would capture both the actual impact of being a teacher and the impact of these unobserved factors. Therefore, the analysis should be viewed as a summary of the observed premium (or deficit) of being a teacher controlling for the variables included in the model.

When calculating total earnings, we combine reported payments in cash as well as payments in kind (if any), such as food and allowances. ${ }^{11}$ However, four of the 15 countries in our African sample (Côte d'Ivoire, the Democratic Republic of Congo, The Gambia, and Tanzania) did not explicitly report the existence and value of in-kind payments; in the comparator group, only Indonesia and Cambodia reported this. It is unclear from the questionnaires whether in these cases in-kind payments are included in the reported values or not. ${ }^{12}$ If inkind payments are included in these cases, our measures of earnings can be interpreted as the total income of an employed person from the primary job. We note, however, that teachers as civil servants receive further benefits that are not likely to be monetized in regular earnings (e.g., retirement benefits; job security) and hence not included in the response to the earnings questions - and these are therefore not included in our analysis.

Indeed, in our data we find that teachers are significantly more likely to report receiving benefits such as paid leave, medical benefits, and a pension than other workers (Table A3). Across our Africa sample, teachers are 31 percentage points more likely to receive paid leave, 9 percentage points more likely to receive medical

\footnotetext{
11 Appendix Table A2 shows the proportion of respondents who reported in-kind payments (median is $16.9 \%$ ) and - for those who did - how much of their income they reported as such (median is $24 \%$ ).

12 This could affect our results if the reported earnings in surveys from those countries did not include in-kind payment, and teachers in those countries were systematically more (or less) likely to receive in-kind payment relative to employees in other professions.
} 
benefits, and 30 percentage points more likely to have a pension. On average, even teachers on fixed term (as opposed to permanent) contracts are more likely to receive benefits: for example, 49 percent of teachers on fixed term contracts report access to paid leave versus only 38 percent of other wage workers (Table A4). ${ }^{13}$ As a result of these other benefits, our salary estimates likely represent an underestimate of the teacher premium.

In our analysis, we separately consider monthly and hourly earnings since hours worked differ systematically between wage workers who are teachers and those who are not. All but one survey we analyze report earnings along with the corresponding time unit of the earnings, for example, daily, weekly, monthly, quarterly, or yearly. Using these two indicators, we first derive implied monthly earnings. For example, if an employee reports her quarterly earnings, then her monthly earnings are calculated as the quarterly earnings divided by three. If daily earnings are reported, we multiply the daily earnings by how many days the person usually works in a week, then multiply that number by four to get monthly earnings. To estimate hourly earnings, we divide the monthly earnings by four times the reported weekly working hours. The Gambia survey did not report working hours, so we exclude them from any analysis involving hourly earnings. (Detailed data processing notes can be found in Appendix Table A1.)

When reporting earnings and performing the multivariate analysis, we limit the sample to wage employees with at least some secondary education to establish a comparable group of professionals to teachers. This is driven by two facts. First, on average only $4.2 \%$ of teachers had less than secondary education in our African sample (Table 2). Therefore, we assume that secondary education is the minimum education requirement for being a teacher in most cases and exclude observations with less than that level of education. Second, teachers either in public or private schools are wage workers. The earnings profiles of wage workers could be systematically different from those workers in the informal sector. For instance, many workers in the informal sector are seasonal, so their earnings would fluctuate substantially. A large share of workers in our African sample were own-account farmers or family helpers who did not report their earnings. Additionally, we trimmed the top and bottom 1 percent of monthly and hourly earnings in each country sample to mitigate the influence of outliers.

To further unpack the earnings differentials for teachers at different education levels, we extended the teacher variable in equation (1) to primary teacher and secondary teacher variables as reflected in equation (2). Again, we fit equation (2) using both OLS and median regressions.

$\ln \left(\right.$ Earning $\left._{i}\right)=\gamma_{0}+\gamma_{1} T_{-}$Primary $_{i}+\gamma_{2} T_{-}$Secondary $_{i}+\gamma_{3}$ Post_secondary $_{i}+\gamma_{4}$ Age $_{i}+\gamma_{5}$ Age $_{i}+\gamma_{6}$ Age $_{i}^{2}+\gamma_{7}$ Male $_{i}+\gamma_{8}$ Urban $_{i}+\varepsilon_{i}(2)$

where $T \_$Primary is an indicator for primary school teachers and $T \_$Secondary is an indicator for secondary school teachers.

\footnotetext{
13 In separate data on a wider range of benefits but asked only of teachers, we find that teachers - particularly civil servant teachers across 10 African countries do report receiving a wide range of benefits (Table A5). For example, 54 percent of teachers in Benin (and 90 percent of civil service teachers) report receiving a housing allowance; those numbers are 67 percent (88 percent) in Côte d'Ivoire. The set of benefits vary across countries, but at least 30 percent of civil service teachers report at least three benefits in each of the 10 countries, and in one (Senegal) they report seven benefits.
} 


\section{Results}

\subsection{Who are the teachers in Africa?}

Before turning to the regression results, we first document the demographic characteristics of teachers and other wage workers (Table 2). A typical teacher in Africa is a 38 years-old male living in an urban area. In absolute terms, teaching is still more likely to be a career for men: on average, three out of five African teachers are male. By way of contrast, the share of male teachers in the comparison countries is slightly under $50 \%$, and three-quarters of teachers are female in the U.S. (NCES, 2018). However, in relative terms, women are more represented in teaching than in other wage jobs where male workers make up an even larger share (73\%); the pattern is similar in the comparator countries—and these findings are consistent with the pattern in high-income countries like the U.S. Indeed, although we observe a lower share of male teachers in the teaching force as national income levels rise across our sample (corr $=-0.60, \mathrm{p}$-value $<0.01, \mathrm{~N}=20$ ), the gender difference between teaching and other wage jobs persists across income levels. For example, in Namibia, the country with the highest GDP per capita in our African sample, $34 \%$ of teachers versus $58 \%$ of other wage workers are male. In Malawi, one of the low-income countries, while the share of male workers is $60 \%$ in teaching, the share is $80 \%$ in other wage jobs.

The average age of African teachers ranges from 35 (in Burkina Faso, The Gambia, Ghana and Zambia) to 45 (in Liberia), with of a median of 38. Teachers are about two years older than other wage workers. Similarly, in the comparator countries, the average age of teachers is 39 while it is 34 for other wage workers . About $60 \%$ of African teachers live in urban areas, which is also where most wage workers are located. Considering the large proportion of African population living in rural areas, especially school-age children, the concentration of teachers in urban areas demonstrates a potential mismatch, consistent with findings from previous research (Bashir et al. 2018; UNESCO, 2019).14

In terms of school type, about $20 \%$ of teachers work in private schools in African countries, a larger proportion than the $14 \%$ in the comparator countries. ${ }^{15}$ This is consistent with the rise of private schools in Sub-Saharan Africa in recent years (World Bank, 2018b). But there is significant variation among the 15 African countries we study, with private school teachers ranging from $5 \%$ (in Namibia) to $38 \%$ (in The Gambia) of the teaching force. In the comparator countries, private school teachers range from $6 \%$ (in Cambodia) to $30 \%$ (in Pakistan). Depending on the nature of a private school (i.e., elite or low-cost) and the contract type, teachers' salary and benefits could vary substantially, which we discuss in section 3.2.

Another important group in the African teaching force is contract teachers. Due to the increasing demand for education, hiring contract teachers is common in Sub-Saharan African countries and other parts of the world (Chudgar, 2015)..$^{16}$ Although their job responsibilities are similar to those of civil-service teachers, their

\footnotetext{
14 The surveys only collected the area an individual lived but not necessarily where the person worked, which would be the ideal way to distinguish whether teachers both lived and worked in urban areas or lived in urban areas but traveled to work in rural areas. The latter is not uncommon in many African countries.

15 Teachers were considered working in private schools unless they reported government (at any level) or any public entity as their employer.

${ }_{16}$ Many countries employ part of their teaching force on short-term, untenured contracts. Research in Kenya and India shows higher test scores for students taught by locally hired teachers on annual contracts (Duflo et al. 2015; Muralidharan and Sundararaman 2013),
} 
salaries are typically substantially lower and they lack job security. In the survey data we use for most countries, all employed respondents—including teachers — are asked whether they have a permanent or a fixed-term/temporary contract. In our sample, the proportion of teachers on fixed term or temporary contracts ranges from 5\% (Tanzania) to 42\% (Côte d'Ivoire) (Table 2). On average, the proportion of teachers on a fixed term or temporary contract is slightly higher for secondary teachers $(25 \%)$ than for primary teachers $(23 \%)$. In Uganda, $74 \%$ of secondary teachers are on a fixed term or temporary contract compared to $33 \%$ of primary teachers.

Table 3 presents the educational attainment of teachers. The majority of teachers have at least secondary school education in all countries in our sample. The only countries where more than 7 percent of teachers have only a primary degree are Côte d'Ivoire (13.5\%) and Zambia (15.8\%). The average educational attainment of teachers in the comparator countries is higher: $86 \%$ have post-secondary education versus $53 \%$ in the African countries. Relative to other wage workers, teachers are much more likely to have postsecondary education in every country in either of our samples except the Democratic Republic of Congo. There is a notable difference in educational attainment between primary school teachers and secondary school teachers in most African countries and Pakistan. On average, $80 \%$ of secondary school teachers have post-secondary education compared to $50 \%$ among primary school teachers. The difference is less salient in Côte d'Ivoire, Nigeria, Uganda, Indonesia, Bolivia and Mexico, where at least $80 \%$ of both primary and secondary teachers have post-secondary education.

\subsection{How has the supply of teachers changed over time?}

Any discussion of salaries makes more sense if we understand the relative supply of workers in the field. We track the proportion of primary school teachers relative to the overall labor force along with the ratio of primary school teachers to students across the countries in our sample of household surveys (Figure 1). ${ }^{17}$ There are no countries in our sample in which the fraction of teachers in the labor force has fallen substantively. The proportion has risen sharply in several countries (e.g., Burkina Faso, Democratic Republic of Congo, Sierra Leone, Tanzania, and Zambia), risen modestly in some (e.g., Côte d'Ivoire and Malawi), and stayed roughly constant in others (e.g., The Gambia). Furthermore, the teacher-student ratio has also risen in many countries (i.e., smaller class sizes), so the rise in teachers cannot entirely be explained by rising enrollment. The average rise across the continent suggests a combination of increasing demand for teachers and that teaching is seen as a desirable profession.

\subsection{What do teachers and other workers earn in Africa?}

We assess teachers' earnings relative to other wage workers in two ways. In this section, we compare monthly earnings, hourly earnings, hours worked weekly and the proportion having a second job (Table 4). In the next section, we report the results of multivariate analyses that simultaneously control for age, gender and geographic location.

although in Kenya, those gains disappeared when the contracts were administered by government rather than by non-government organizations (Bold et al. 2018).

17 There are far more missing data among secondary school teachers and so those results are not informative. 
The median earnings of teachers identified in our African surveys is about $\$ 680$ per month (measured at the 2011 purchasing power parity (PPP) exchange rate), and teachers in the comparator countries earn about $\$ 860$ (Column 1, Table 4). There is, however, very large cross-country variation in these monthly earnings. Teachers make $\$ 100$ per month in the Democratic Republic of Congo, $\$ 220$ in Liberia, $\$ 400$ in Niger, $\$ 640$ in Ghana, $\$ 800$ in Tanzania, $\$ 1,600$ in Zambia, and $\$ 2,300$ in Namibia. In the comparator sample monthly earnings for teachers range from $\$ 420$ in Cambodia to about $\$ 1,200$ in Bolivia and Mexico.

One often-used way to put these numbers in context is to express teacher earnings in relation to GDP per capita. Column 2 of Table 4 reports that on average teachers in the African sample are paid 300 percent of GDP per capita, again with large variation across countries. Burkina Faso and Zambia pay their teachers around 500 percent of GDP per capita, and at the other extreme, Nigeria pays its teachers only 90 percent of GDP per capita. In the comparator sample, teachers earn about 140 percent of GDP per capita, similar to the OECD average of 130 percent (OECD, 2011). Plotting these numbers by countries' GDP per capita (Figure 2), we find suggestive evidence of a negative correlation between teacher monthly earnings as a ratio of GDP per capita and a country's income level. In other words, teachers' salaries rise as national income rises, but at a slower rate than national incomes. While this suggests that teachers in lower-income countries are relatively better off than those in higher-income countries, the poor living and working conditions in many low- and lower middle-income countries in our sample mean that even being paid several times the GDP per capita does not mean teachers enjoy the same quality of life as teachers in upper-middle- or high-income countries (Evans and Yuan, 2018).

Across countries in our sample, teachers are paid either a lower or comparable monthly salary to other wage workers with similar educational background in three-quarters of African countries and all the comparator countries (Columns 1-4, Table 4). However, teachers in all countries in our sample work significantly fewer hours per week, about 36 hours among teachers compared to 49 hours among other workers (Columns 7-8, Table 4). After scaling monthly earnings by hours worked, the results show that teachers are paid more on an hourly basis than other workers in every country except the Democratic Republic of Congo, The Gambia, Liberia and Niger. Furthermore, teachers are more likely to take a second job in almost every country, which suggests that teachers may want (or need) to work more to make higher earnings (Table 4, last two columns). ${ }^{18}$ However, we do not observe an association between reported hours worked by teachers and the propensity to take a second job ( $\operatorname{corr}=0.25$, $\mathrm{p}$-value $=0.32, \mathrm{~N}=18)$.

Who are these other wage workers? To better understand the relationship between teacher pay and that of other secondary and post-secondary graduates to whom we compare them, we summarize the broad occupations of these other workers and summarize their earnings, separated into those with secondary and those with post-secondary education. We classify occupations using the International Labor Organization codes from the household surveys (ILO 2012). While there is variation across countries, across our Africa sample we see that among wage workers with secondary education, only one occupation - managers - earns more than teachers (Table 5A). Among wage workers with post-secondary education, there are just three occupations that earn more than teachers: managers, professionals, and skilled agricultural workers (Table 5B). Teachers are relatively less well-paid in our comparison countries, with managers, professionals,

\footnotetext{
${ }^{18}$ See Appendix Table A6 for earnings of different teacher groups: teacher in public schools; primary school teachers; and secondary
} school teachers. 
technicians, clerks, and machine operators all earning more at the secondary level and managers, professionals, and technicians earning more at the post-secondary level. ${ }^{19}$

Another earnings-related question is whether teacher pay is less linked to performance in general than that of other workers. As a partial test of this, we compare how much variation in teacher pay is explained by observable characteristics relative to pay for other workers. Specifically, we regress monthly earnings on gender, age (and its square), education, and urban status for teachers and for all other workers and compare the $\mathrm{R}$-squared $\left(\mathrm{R}^{2}\right)$, a measure of how variation is captured by these observed characteristics. ${ }^{20}$ We find that in our Africa sample on average, teacher pay is slightly less explained by observed characteristics $\left(\mathrm{R}^{2}\right.$ of 0.21$)$ than that of other workers ( $\mathrm{R}^{2}$ of 0.27$)$. In our comparator sample, we observe the opposite pattern, with an $\mathrm{R}^{2}$ of 0.29 for teachers and 0.24 for other workers. Even in Ghana, the country in our sample with the highest $\mathrm{R}^{2}$ for teachers, less than half of teacher pay is explained by observed characteristics. These are not monumental differences, and since we are running separate regressions, we cannot test whether the differences are statistically significant. But these statistics do push against the idea that teacher pay is much more likely to be determined by age and education (rather than performance) than other fields in Africa.

If we divide teachers by contract type, we find that on average, the median monthly earnings of fixed term contract teachers are just 71 percent of the earnings of permanent teachers in our Africa sample (Table 6). The ratio ranges from just 36 percent in Burkina Faso (similar to Pakistan in our comparator sample) to 91 percent in the Democratic Republic of Congo and over 100 percent in Sierra Leone. The high number in Sierra Leone is driven entirely by secondary school teachers. At the primary level, teachers on fixed term contracts earn less than teachers on permanent contracts in every country. The range is similar for the ratio of hourly wages, suggesting that teachers on permanent and fixed term contracts report similar working hours (Table 7).

\subsection{How are teachers paid relative to other professionals, adjusting for controls?}

Table 8 reports the monthly earnings differentials estimated by multivariate regression analyses which control for education, age (and its square), gender, and rural/urban location. We first estimate the model for all teachers using OLS and median regression (Columns 1 and 2 respectively). We then replace the teacher dummy with primary-teacher and secondary-teacher dummies in the OLS regression (Columns 3 and 4). Next, we keep only teachers in public schools and remove all other teachers from the sample (Column 5). Last, we estimate the same model but limit the sample to public-sector employees to compare how publicschool teachers are paid compared to other public sector employees (Column 6).

In five of the 15 African countries in the sample (Burkina Faso, Côte d'Ivoire, Namibia, Senegal and Zambia), teachers enjoy a monthly earnings premium that averages $38 \%$. In three of the African countries (Ghana, Malawi, and Niger), teachers earn similar amounts to comparable wage workers. In the remaining seven

\footnotetext{
${ }^{19}$ We also do this comparison by sector (Tables A7 and A8), using UN sector classification codes (UN 2007). With secondary education, teachers earn more than workers in any sector except mining. With post-secondary education, teachers are much lower: post-secondary workers in agriculture, mining, manufacturing, construction, financial services, health and social services, and public administration all earn more. Only workers in retail and administrative services earn less.

${ }^{20}$ We group all workers other than teachers in order to ensure reasonable sample sizes.
} 
African countries, teachers suffer a deficit in earnings relative to comparable wage workers that averages $26 \%$. Among the comparator group countries, it is only teachers in Mexico who show an earnings premium (of $5 \%$ ). In three of the countries, teachers suffer a deficit of between $12 \%$ and $28 \%$ (Cambodia, Indonesia, Pakistan). In Bolivia, teachers are paid similarly to comparable workers. This basic set of results is robust to whether we use OLS or median regression, although the point estimates vary for some countries (additional median results are reported in Appendix Tables A10 and A11). ${ }^{21}$

Given that most teachers are in primary schools, and that most are in public schools, it is unsurprising that the results are similar when we focus on those subsets of the sample. The results suggest that, in general, when public sector teachers have an earnings premium relative to comparable workers, they also have a premium relative to other public sector employees—although this premium is smaller. In these five countries, therefore, this indicates a "hierarchy" of premiums (with teachers having the higher premium). In countries where public sector teachers have an earnings deficit relative to comparable workers, they also tend to face a deficit relative to other public sector employees (with these magnitudes often being similar). The results for secondary school teachers are different: in many more cases these teachers are paid similarly to comparable workers. There are six African countries (out of 14 for which we can estimate this) where there is a statistically significant earnings deficit for teachers (which averages 30\%); two African countries where there is a premium for teachers; and in the remaining six countries there is no statistically significant difference. This pattern of secondary teachers being more similar to comparable workers is also found in the comparator countries.

With respect to hourly earnings, there are substantially more systematic patterns. Teachers have a statistically significant hourly-earnings premium in eight of the 14 African countries, and in three of the five comparator countries. Hourly-earnings deficits are rare, but nevertheless evident in Nigeria and Indonesia (Table 9). Averaging across all values (positive and negative, statistically significant and non-significant), the hourly wage premium for teachers in African countries is 27 percent and 19 percent in the comparator countries. Recall that in monthly earnings terms these averages were close to zero (which masked substantial heterogeneity). The overall pattern is once again similar when using median regression.

The results are also similar when restricting the analysis to primary school teachers or to public school teachers. Public sector teachers tend to have either no premium or a positive hourly earnings premium when compared to other public sector employees (12 of the 14 countries for which this could be estimated). In only two countries (Tanzania and Uganda) do they have a deficit relative to comparable civil servant employees. Last, the hourly earnings premiums are typically also found for secondary school teachers (i.e., these are now more in line with teachers overall/primary school teachers).

Across contract types, earning premia are higher (or less negative) for teachers with permanent contracts than for teachers with fixed-term contracts. For both monthly and hourly wages, there are more statistically significant premia for permanent contract teachers than for fixed-term contract teachers (Table 10).

\footnotetext{
${ }^{21}$ If we include teachers and comparator workers with primary education in the regressions, then the teacher premium rises, which is unsurprising since non-teachers with only a primary school education make less.
} 


\subsection{Correlations}

\subsubsection{Teacher pay and student performance}

We examine the cross-country association between teacher earnings premiums and student achievement using two measures: first, the harmonized test scores from the Human Capital Index database, recently developed by the World Bank (2018a); second, the rate of "learning poverty" defined as the share of children who are unable to read and understand a simple text by age 10 (World Bank, 2019a). For more details on these measures and our empirical specification, see Appendix 1. Figures 3 and 4 provide visual evidence of the association between teacher earnings differentials and student performance. Figure 3 shows the cross-country relationship of the teacher monthly earnings differential (relative to comparable workers) and harmonized student test scores among African countries (Panel A) and all countries (Panel B). In both panels, the monthly earnings differential for teachers is positively associated with student test scores. In African countries, a 100\% earnings premium is associated with a 41-point increase in harmonized test score, which is about 0.6 of a standard deviation across all the global harmonized test scores (Table 11). Moreover, we observe a similar positive association in Figure 4 that plots the teacher hourly earnings differentials against student test scores. These associations are statistically significant at conventional levels (Table 11).22

When we use the rate of learning poverty as a proxy for student performance, we also find an association (this time negative, consistent with the HLO results) between the teacher earnings differential and the proportion of children living in learning poverty. However, because of incomplete data coverage, only 10 countries are included in the analysis and the results are not statistically significant (Table 11).

In our final examination of the association between student learning and salaries, we use microdata from 10 Francophone African countries which include test scores for students and self-reported monthly salaries of teachers (see Appendix 1 for details). ${ }^{23}$ We estimate the model both without and with a set of controls (Table A12 Columns 1-6 and 7-12 respectively). We find strongly statistically significant, positive associations when pooling the data across countries in both specifications. This is the case in Grades 2 and 6 combined, in Grade 2, and in Grade 6 without controls; the coefficient is still positive but no longer statistically significant in Grade 6 with controls. When carrying out the analysis country-by-country, the positive association holds in Grades 2 and 6 in eight countries (six with controls) and is statistically significantly positive in five countries (three with controls). With controls, there are two countries with statistically significant negative associations (Benin and Burundi). On the whole, the microdata are consistent with the notion that better paid teachers are in schools with higher performing students. This may or may not be the result of a causal relationship: we cannot, for example, rule out that the best teachers are paid more and are sent to schools with better students—although our controls do capture teacher education and experience.

\footnotetext{
22 As is visible in Figures $3 \mathrm{a}$ and $4 \mathrm{a}$, the association is driven by two groups of countries: those with low premia and low test scores and those with higher premia and higher test scores. Within these groups the association is close to zero and not statistically significant, although samples are small.

${ }^{23}$ Note that this is no longer examining the relative pay of teachers-rather the absolute level.
} 


\subsubsection{Teacher pay and other aspects of the economy}

How do teacher wages change as structural aspects of economies change? We explore the correlations between teacher wage differentials and key macroeconomic indicators like growth in GDP and GDP per capita; labor market indicators like formal sector size and female labor participation; and political economy factors such as the level of teacher unionization. ${ }^{24}$ None of these indicators shows a statistically significant association with either the monthly or the hourly earnings differentials for teachers. We also examine the correlation between teacher wage premia and teachers as a fraction of the labor force; and the change in teachers as a fraction of the labor force. Both relationships are positive but not statistically significant. (All these correlations and their statistical significance are reported in Appendix Table A13.) Thus, we see no evidence that teacher wage differentials are more pronounced in richer economies, more formal economies, economies with more women in the labor force, or even with teacher unionization. The lack of association between teacher unionization and teacher wage differentials is consistent with evidence from the United States (Frandsen 2016; Paglayan, 2019). ${ }^{25}$

\section{Conclusion}

In this paper, we present new evidence on teacher salaries across a set of 15 African and five comparator countries. We document key descriptive statistics about the level of teacher salaries and show the relationship of teacher salaries to other workers of comparable education and experience in the same economies. Our results may explain part of the contention between those who argue that teachers are paid too little and those who argue that teachers are paid too much (Das, 2017). In several countries in our sample, teachers are often paid less than comparable workers in terms of their monthly income, but they are paid more than others per hour. In several countries, the wage gap between teachers on fixed term and permanent contracts is large. Teachers are much more likely to take a second job than other workers. We also document that teachers receive a wide range of benefits that other workers tend not to receive, so wage estimates for teachers should be seen as underestimates.

One of our objectives in this research was to identify general lessons across African countries, some of which share languages and legal structures. But these results highlight the danger of adopting a single narrative about compensation for teachers or other public sector workers. Extrapolating from a single case-whether it is Pakistan or Ghana-is unlikely to be instructive when teacher pay differentials and the structure of teacher pay vary so much from country to country, even on the same continent. Growth in the teaching labor force over time varies widely across countries. Monthly wage premia for teachers range from strongly positive (Zambia) to strongly negative (Liberia). Hourly wage premia likewise vary dramatically, although we do not observe strong negative premia in that case. The variation in earnings across teachers-even restricting only to teachers on permanent contracts - differs greatly, from low variation in Sierra Leone to high variation in Burkina Faso. The most obvious structural candidates to explain some of these differences, like the rate of teacher unionization or the formality of the labor force, are uncorrelated with teacher wage premia.

\footnotetext{
24 The macroeconomic indicators and labor market indicators are drawn from the World Development Indicators database (World Bank, 2019c). The level of teacher unionization is derived from the survey data used in this paper. A teacher is considered to be a union member if she answered yes to a survey question like "Do you belong to a union?"

${ }^{25}$ Frandsen (2016) does find that increased unionization reduces teacher hours in the United States.
} 
Ultimately, there is no clear, single narrative on teacher compensation that explains the wide variation in the structure of teacher labor markets.

While teacher wage differentials appear unrelated to a range of structural factors in the economy, teacher salaries do tend to rise slower than national incomes do. The association (and that is all we observe) between teacher wage differentials and student learning outcomes_-both across and within countries—-merits further exploration beyond the short-term impacts of wage changes on the performance of existing teachers, in order to observe how selection effects may change the net impact on student learning. 


\section{References}

Ahimbisibwe, P. (2019, May 21) No money for teachers' salary raise - government. The Daily Monitor. Retrieved from https://www.monitor.co.ug/News/National/No-money-teachers--salary-raisegovernment/688334-5124224-1iat17/

Araujo, M. C., Carneiro, P., Cruz-Aguayo, Y., \& Schady, N. (2016). Teacher quality and learning outcomes in kindergarten. The Quarterly Journal of Economics, 131 (3), 1415-1453.

Barrera-Osorio, F., \& Raju, D. (2017). Teacher performance pay: Experimental evidence from Pakistan. Journal of Public Economics, 148, 75-91.

Bashir, S., Lockheed, M., Ninan, E., \& Tan, J. P. (2018). Facing forward: Schooling for learning in Africa. The World Bank.

Bau, N., \& Das, J. (2017). The misallocation of pay and productivity in the public sector: Evidence from the labor market for teachers. Policy Research Working Paper No. 8050. The World Bank.

Blanc, E. (2019). Red State Revolt: The Teachers' Strike Wave and Working-class Politics. Verso Books.

Bold, T., Filmer, D., Martin, G., Molina, E., Stacy, B., Rockmore, C., ... \& Wane, W. (2017). Enrollment without learning: Teacher effort, knowledge, and skill in primary schools in Africa. Journal of Economic Perspectives, 31(4), 185-204.

Bold, T., Kimenyi, M., Mwabu, G., \& Sandefur, J. (2018). Experimental evidence on scaling up education reforms in Kenya. Journal of Public Economics, 168, 1-20.

Buron, C.G., \& Lassibile, G. (2016). Job Satisfaction among Primary School Personnel in Madagascar. Journal of Development Studies. 52(11).

Cabrera, J. M., \& Webbink, D. (2018). Do higher salaries yield better teachers and better student outcomes? MPRA working paper series. Retrieved from https://mpra.ub.unimuenchen.de/86972/1/MPRA paper 86972.pdf

Chetty, R., Friedman, J. N., \& Rockoff, J. E. (2014). Measuring the impacts of teachers II: Teacher valueadded and student outcomes in adulthood. American Economic Review, 104(9), 2633-2679.

Cilliers, J., Kasirye, I., Leaver, C., Serneels, P., \& Zeitlin, A. (2018). Pay for locally monitored performance? A welfare analysis for teacher attendance in Ugandan primary schools. Joumal of Public Economics, 167, 69-90.

Chudgar, A. (2015). Association between contract teachers and student learning in five Francophone African countries. Comparative Education Review, 59(2), 261-288.

Dal Bó, E., Finan, F., \& Rossi, M. A. (2013). Strengthening State Capabilities: The Role of Financial Incentives in the Call to Public Service The Quarterly Journal of Economics, 128(3), 1169-1218.

da Conceição, L. (2017, September 12). Moçambique: Professores de Tete em greve por falta de salários. DW. Retrieved from https://www.dw.com/pt-002/mo\%C3\%A7ambique-professores-de-tete-em-greve-porfalta-de-sal $\%$ C $3 \%$ A 1 rios $/ \mathrm{a}-41723964$

da Silva Filho, G. A., \& de Xavier Pinto, C. C. (2014). Higher Salaries, More Teaching, Better Performance? Unpublished manuscript. Retrieved from https://editorialexpress.com/cgibin $/$ conference $/$ download.cgi? db name $=$ SBE36\&paper $\mathrm{id}=94$

Das, J. (2017, July 21). Teachers' salaries: Too many bucks for the bang? Future Development at Brookings. Retrieved from https://www.brookings.edu/blog/future-development/2017/07/21/teachers-salariestoo-many-bucks-for-the-bang/

De Ree, J., Muralidharan, K., Pradhan, M., \& Rogers, H. (2018). Double for nothing? The effect of unconditional teachers' salary increases on performance. Quarterly Journal of Economics. 133 (2): 993-1039.

Dolton, P., Marcenaro-Gutierrez, O., Pistaferri, L., \& Algan, Y. (2011). If you pay peanuts do you get monkeys? A cross-country analysis of teacher pay and pupil performance. Economic Policy, 26(65), 5, 7-55.

Duflo, E., Dupas, P., \& Kremer, M. (2015). School governance, teacher incentives, and pupil-teacher ratios: Experimental evidence from Kenyan primary schools. Journal of public Economics, 123, 92-110.

Evans and Yuan. (2018). The Working Conditions of Teachers in Low- and Middle-Income Countries. RISE Conference paper. Retrieved from https://www.riseprogramme.org/sites/www.riseprogramme.org/files/inline-files/Yuan.pdf

Ferraz, C., \& Finan, F. (2009). Motivating Politicians: The Impacts of Monetary Incentives on Quality and Performance. NBER Working Paper No. 14906. 
Finan, F., Olken, B. A., \& Pande, R. (2017). The personnel economics of the developing state. In Handbook of Economic Field Experiments (Vol. 2, pp. 467-514): Elsevier.

Frandsen, B.R. (2016). The Effects of Collective Bargaining Rights on Public Employee Compensation: Evidence from Teachers, Firefighters, and Police. ILR Review, 69(1), 84-112.

Gilligan, D.O., Karachiwalla, N., Kasirye, I., Lucas, A.M., \& Neal, D. (2019). Educator Incentives and Educational Triage in Rural Primary Schools. Journal of Human Resources. In Press.

Gregory, R. G., \& Borland, J. (1999). Recent developments in public sector labor markets. Handbook of labor economics, 3, 3573-3630.

Hanushek, E. A., Piopiunik, M., \& Wiederhold, S. (2019). The Value of Smarter Teachers International Evidence on Teacher Cognitive Skills and Student Performance. Journal of Human Resources, 54(4), $857-$ 899.

Hanushek, E. A., \& Rivkin, S. G. (2010). Generalizations about using value-added measures of teacher quality. American Economic Review, 100(2), 267-271.

International Labour Organization. (2012). International Standard Classification of Occupations: ISCO-08. Geneva: ILO. Retrieved from https://www.ilo.org/public/english/bureau/stat/isco/docs/publication08.pdf

International Labour Organization. (2020). ILOSTAT: The leading source of labour statistics. Retrieved from. https://ilostat.ilo.org/data/

Jackson, C. K. (2012). Recruiting, retaining, and creating quality teachers. Nordic Economic Policy Review, 3(1), 61-104.

Kumar, S., and Kumar, N. (2019, January 25). Striking Tamil Nadu teachers denounce state and central governments. The World Socialist Web Site. Retrieved from https://www.wsws.org/en/articles/2019/01/25/tnin-j25.html

Leaver, C., Ozier, O., Serneels, P., and Zeitlin, A. (2019). "Recruitment, effort, and retention effects of performance contracts for civil servants: Experimental evidence from Rwandan primary schools.” RISE Conference paper. Retrieved from https://www.riseprogramme.org/sites/www.riseprogramme.org/files/inlinefiles/20190620\%20Zeitlin.pdf

Mbiti, I., Muralidharan, K., Romero, M., Schipper, Y., Manda, C., \& Rajani, R. (2019). Inputs, incentives, and complementarities in education: Experimental evidence from Tanzania. The Quarterly Journal of Economics, 134(3), 1627-1673.

Mexico News Daily. (2019). Oaxaca teachers declare strike action, erect blockades. January 29. https://mexiconewsdaily.com/news/oaxaca-teachers-declare-strike-action-erect-blockades/ (retrieved March 20, 2020)

Mincer, J. (1974). Schooling, Experience, and Earnings. Human Behavior \& Social Institutions No. 2.

Mizala, A., \& Ñopo, H. (2016). Measuring the relative pay of school teachers in Latin America 1997-2007. International Journal of Educational Development, 47, 20-32.

Muralidharan, K., \& Sundararaman, V. (2011). Teacher performance pay: Experimental evidence from India. Joumal of political Economy, 119(1), 39-77.

Muralidharan, K., \& Sundararaman, V. (2013). Contract teachers: Experimental evidence from India . NBER Working Paper No. 19440.

NCES. (2018). Characteristics of Public School Teachers. https://nces.ed.gov/programs/coe/indicator_clr.asp

OECD. (2011). How much are teachers paid. Education at a Glance. Retrieved from http://www.oecd.org/education/skills-beyond-school/48631286.pdf

Paglayan, A. S. (2019). Public-Sector Unions and the Size of Government. American Journal of Political Science, 63(1), 21-36.

Programme d'analyse des systèmes éducatifs de la confemen (PASEC). (2015). PASEC 2014: Education System Performance in Francophone Sub-Saharan Africa. Retrieved from https://www.pasec.confemen.org/wp-content/uploads/2015/12/Rapport_Pasec2014_GB webv2.pdf

Pugatch, T., \& Schroeder, E. (2014). Incentives for teacher relocation: Evidence from the Gambian hardship allowance. Economics of Education Review, 41, 120-136. 
Reuters. (2019). Start of Argentina school year postponed by teachers' strike. March 6.

https://www.reuters.com/article/us-argentina-strike/start-of-argentina-school-year-postponed-byteachers-strike-idUSKCN1QN26B (Retrieved March 20, 2020)

United Nations Statistics Division. (2007). International Standard Industrial Classification of All Economic Activities Revision 4, Series M: Miscellaneous Statistical Papers, No. 4 Rev. 4, New York: United Nations. Retrieved from https://unstats.un.org/unsd/classifications/Family/Detail/27

UNESCO. (2020). Institute for Statistics Education Statistics. Retrieved from: http://data.uis.unesco.org/

UNESCO. (2016). The World Needs Almost 69 Million New Teachers to Reach the 2030 Education Goals. Retrieved from http://uis.unesco.org/sites/default/files/documents/fs39-the-world-needs-almost-69-million-newteachers-to-reach-the-2030-education-goals-2016-en.pdf

U.S. Bureau of Labor Statistics. (2018). May 2018 National Occupational Employment and Wage Estimates United States. Retrieved from https://www.bls.gov/oes/current/oes nat.htm\#25-0000

World Bank. (2018a). The Human Capital Project (HCP). https://www.worldbank.org/en/publication/human-capital

World Bank. (2018b). Learning: To Realize Education's Promise. World Bank Group.

World Bank. (2019a). Learning Poverty. https://www.worldbank.org/en/topic/education/brief/learningpoverty

World Bank. (2019b). World Bank Country and Lending Groups. https://datahelpdesk.worldbank.org/knowledgebase/articles/906519-world-bank-country-and-lendinggroups

World Bank. (2019c). World Development Indicators. https://datacatalog.worldbank.org/dataset/worlddevelopment-indicators 


\section{Figures and tables}

Figure 1. Trends in Primary School Teachers/Students and in Primary School Teachers/Labor Force
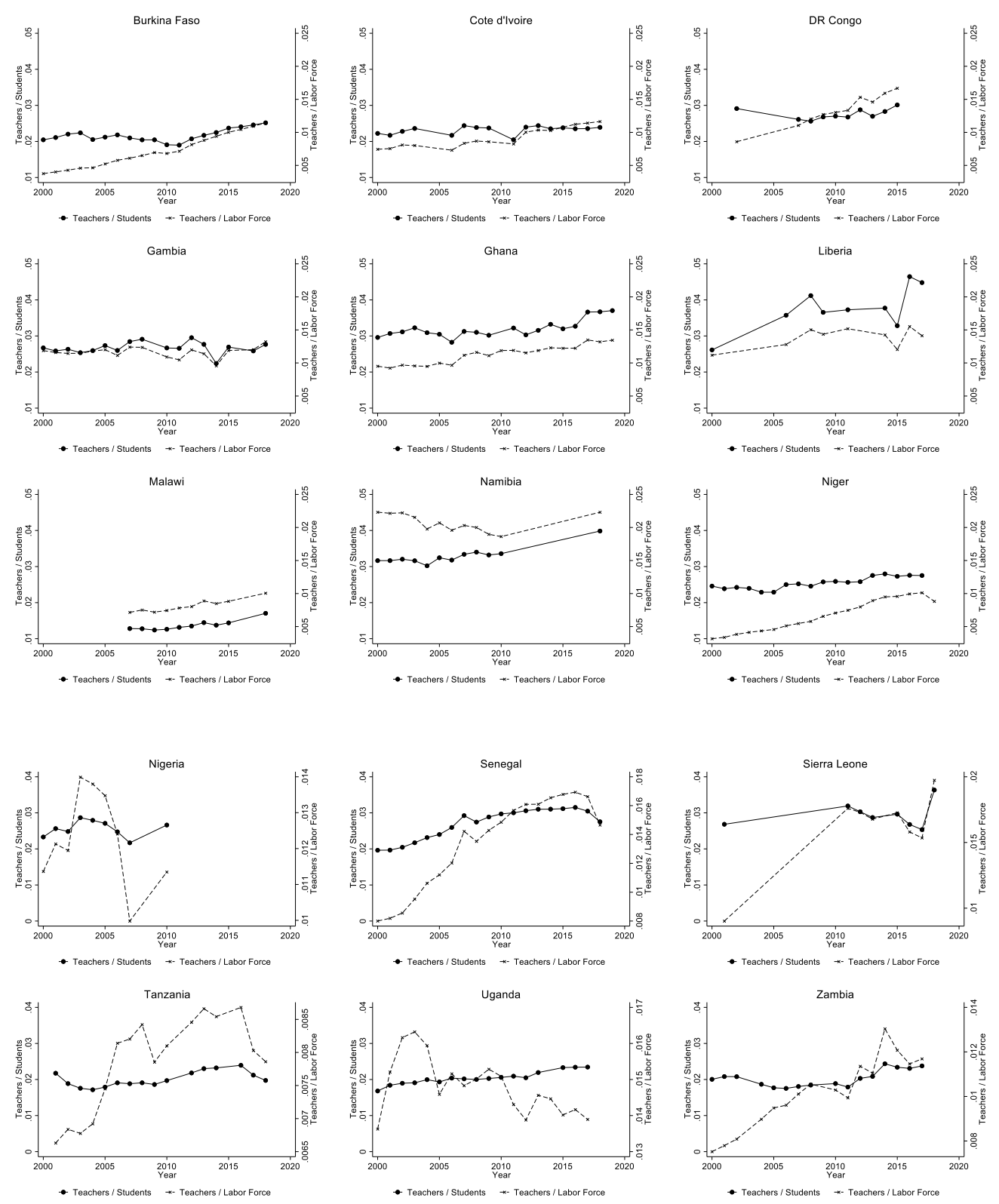

Source: Number of students and number of teachers from UNESCO Institute for Statistics. Labor force is modelled labor force aged 15-64 from International Labor Organization. 
Figure 2. Teacher monthly earnings as a ratio of GDP per capita

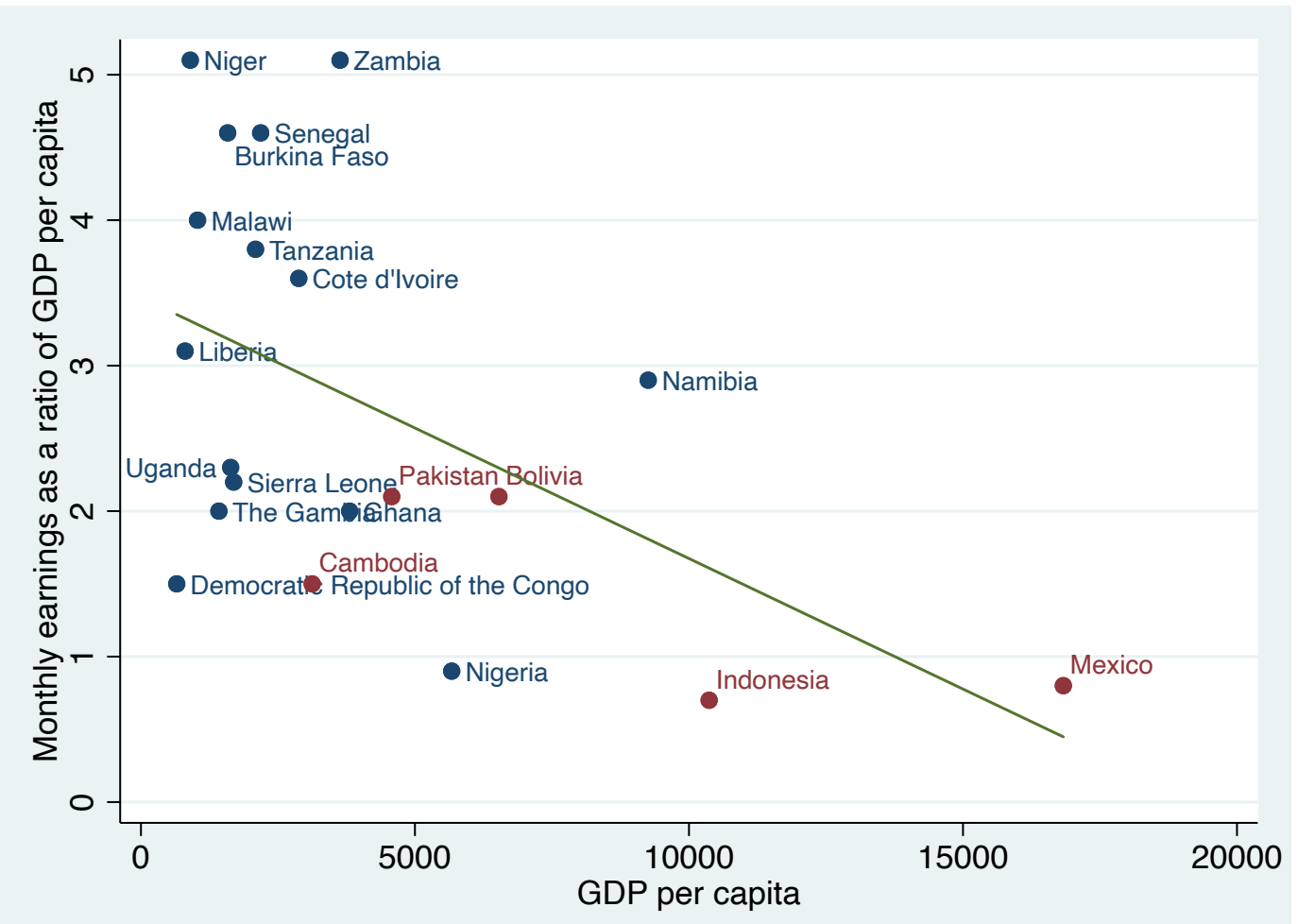

Notes: African countries are in blue dots, and the comparator countries are in red dots. The green line is the line of best fit. Sources: See Table 1 for survey data sources and year. GDP per capita data are from World Development Indicators (World Bank, 2019c). 
Figure 3. Teacher monthly earnings differential and student performance

Panel A: African countries only

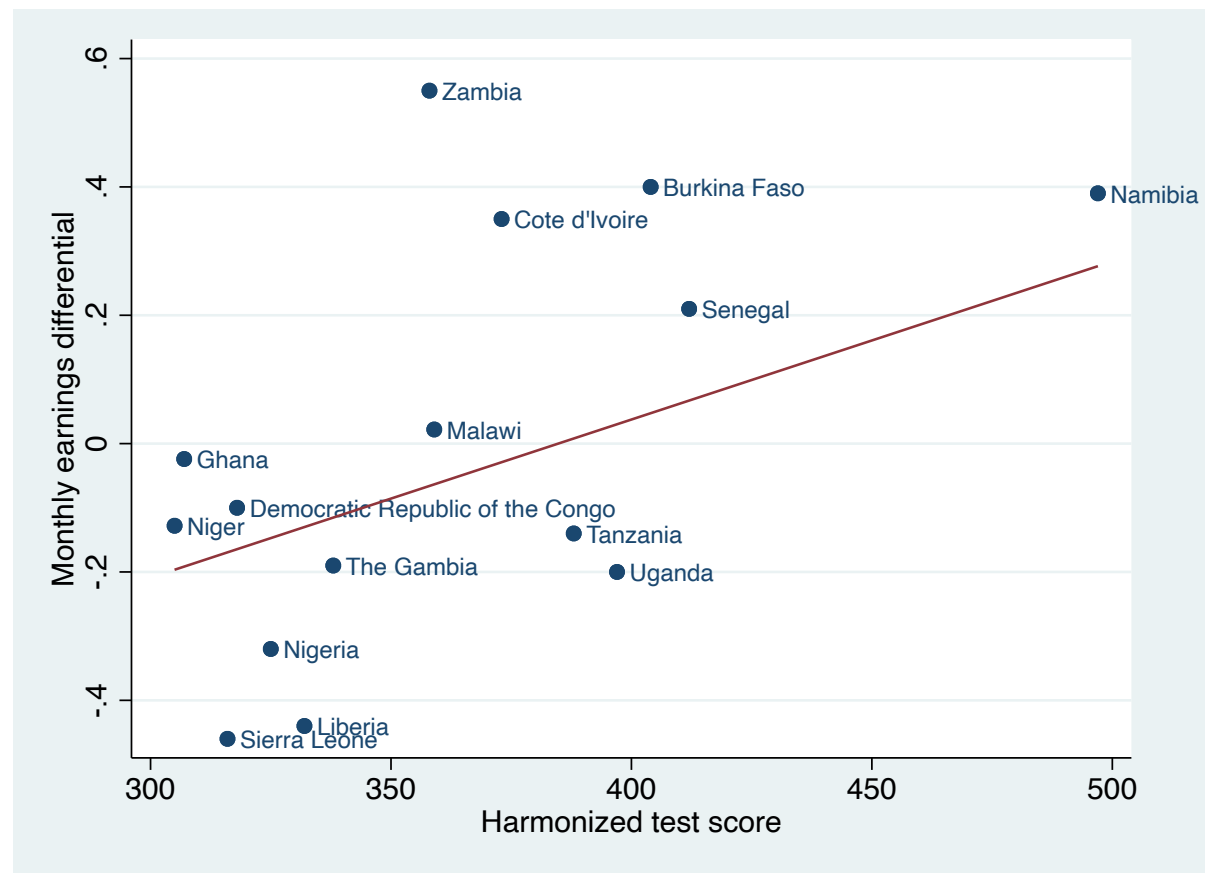

Panel B: All countries

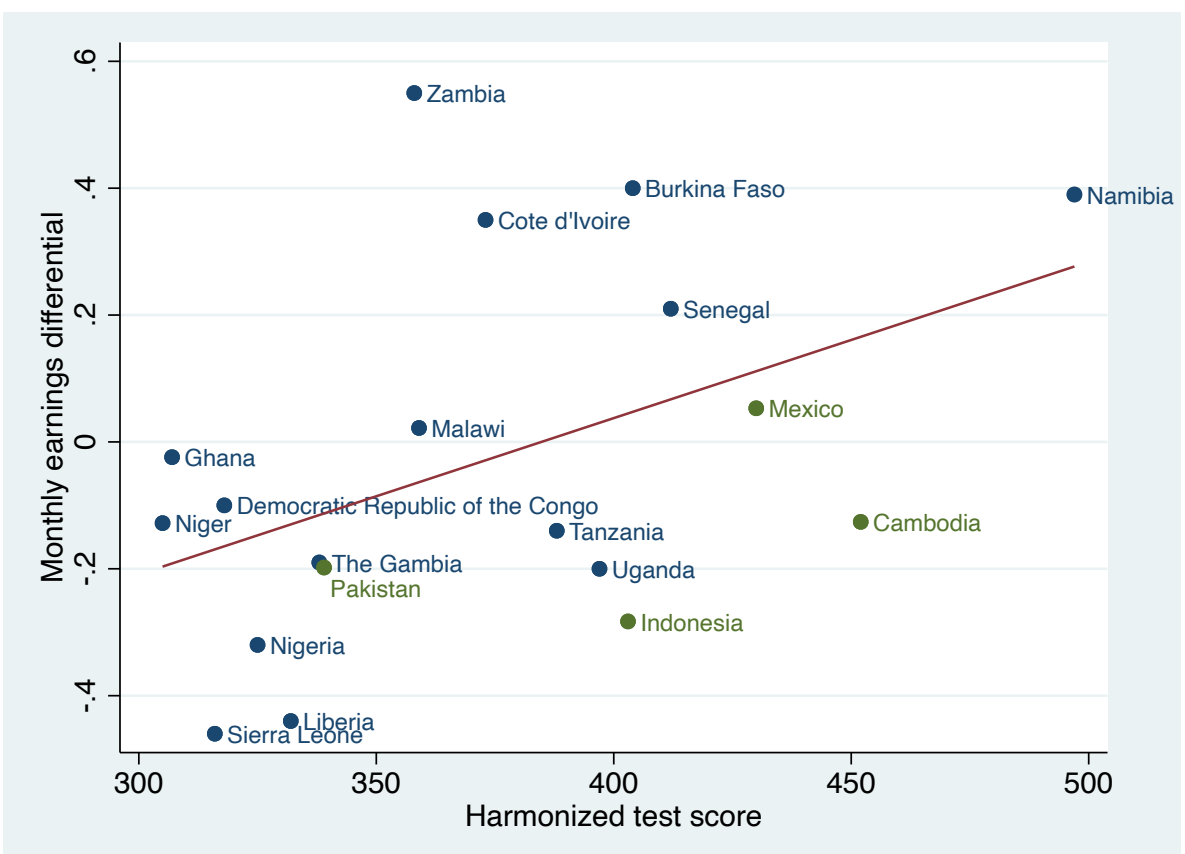

Notes: African countries are in blue dots, and the comparator countries are in red dots. The green line is the line of best fit. Sources: See Table 1 for survey data sources and year. Harmonized test scores are from the Human Capital Index dataset (World Bank, 2018 a). 
Figure 4. Teacher hourly earnings differential and student performance

Panel A: African countries only

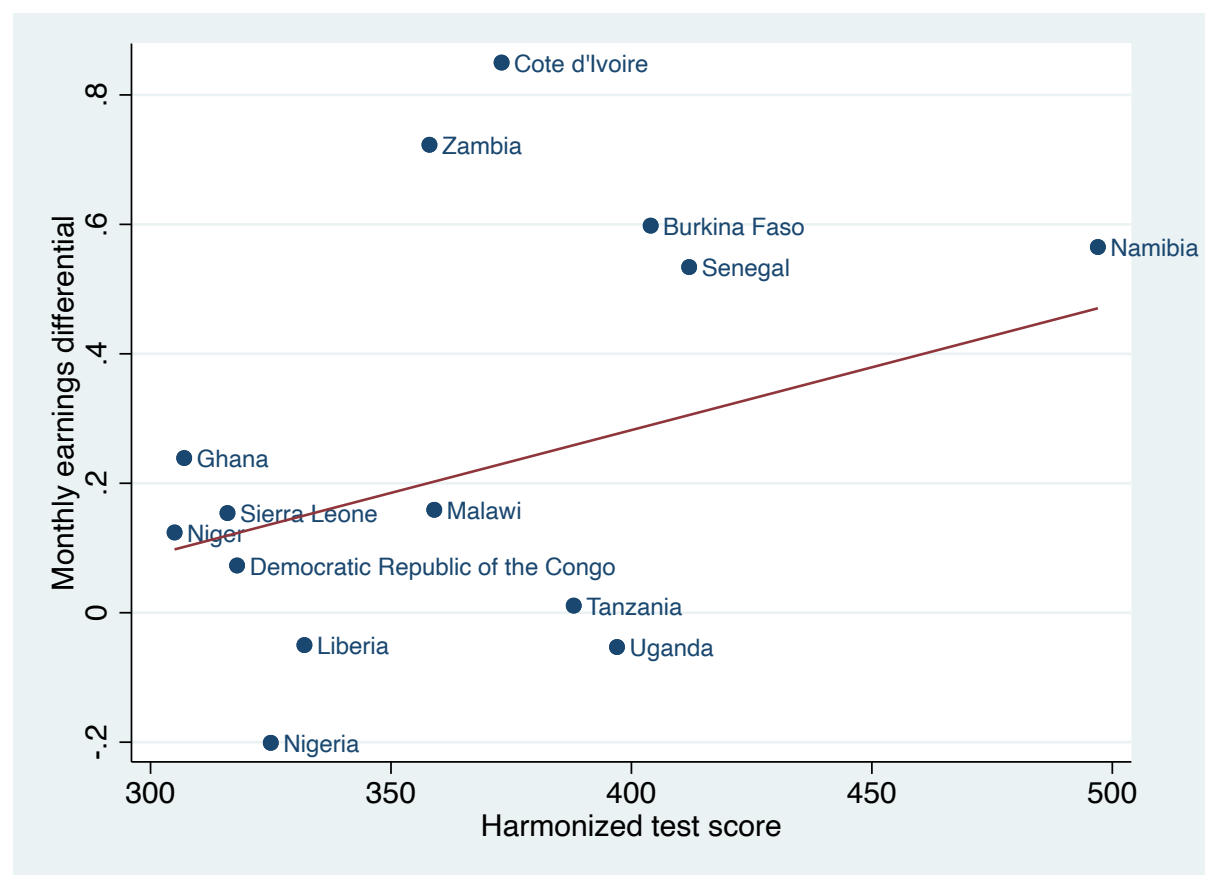

Panel B: All countries

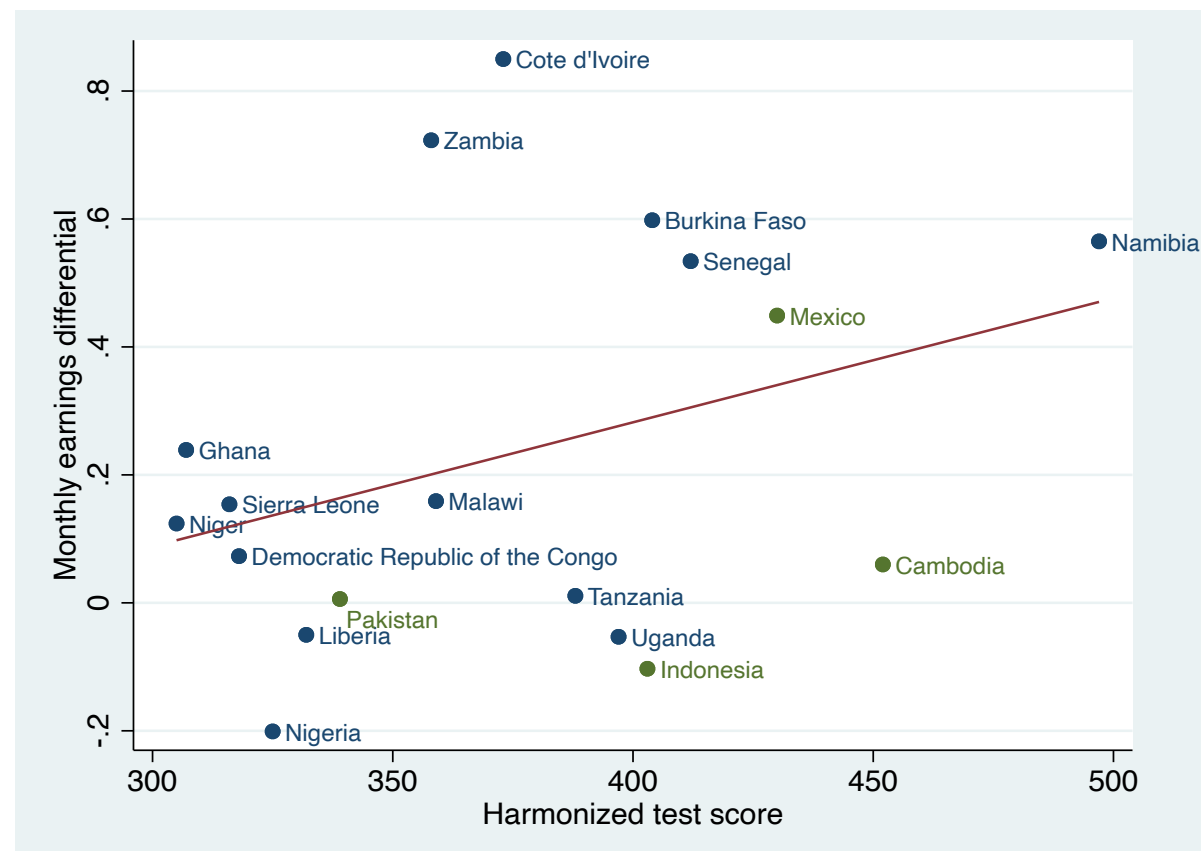

Notes: African countries are in blue dots, and the comparator countries are in red dots. The green line is the line of best fit. Sources: See Table 1 for survey data sources and year. Harmonized test scores are from the Human Capital Index dataset (World Bank, 2018 $\underline{a})$. 
Table 1. Description of datasets

\begin{tabular}{|c|c|c|c|c|c|}
\hline Country & Source & Year & $\begin{array}{l}\text { Number } \\
\text { surveyed }\end{array}$ & $\begin{array}{c}\text { Teachers } \\
\text { Percent of total } \\
\text { surveyed wage } \\
\text { workers }\end{array}$ & $\begin{array}{c}\text { Percent of total } \\
\text { surveyed work } \\
\text { force (ages 15-64) }\end{array}$ \\
\hline \multicolumn{6}{|l|}{ Panel A: African countries } \\
\hline Burkina Faso & Continuous Multisectoral Survey & 2014 & 343 & $13 \%$ & $1.3 \%$ \\
\hline Côte d'Ivoire & National Employment Survey & 2013 & 201 & $6 \%$ & $1.1 \%$ \\
\hline Democratic Republic of Congo & National Household Survey & 2012 & 1,104 & $18 \%$ & $3.1 \%$ \\
\hline The Gambia & Integrated Household Survey & 2010 & 243 & $10 \%$ & $1.9 \%$ \\
\hline Ghana & Ghana Living Standards Survey 6 & 2012-2013 & 772 & $16 \%$ & $2.4 \%$ \\
\hline Liberia & $\begin{array}{l}\text { Household Income and Expenditure } \\
\text { Survey }\end{array}$ & 2014-2015 & 171 & $14 \%$ & $2.2 \%$ \\
\hline Malawi & Integrated Household Panel Survey & 2010 & 393 & $12 \%$ & $1.9 \%$ \\
\hline Namibia & Labor Force Survey & 2013 & 359 & $8 \%$ & $3.7 \%$ \\
\hline Niger & $\begin{array}{l}\text { National Survey on Household Living } \\
\text { Conditions and Agriculture }\end{array}$ & 2014 & 119 & $12 \%$ & $1.6 \%$ \\
\hline Nigeria & General Household Survey & 2015 & 240 & $20 \%$ & $2.8 \%$ \\
\hline Senegal & Poverty Monitoring Survey & 2010 & 331 & $7 \%$ & $0.8 \%$ \\
\hline Sierra Leone & Labor Force Survey & 2014 & 220 & $27 \%$ & $3.1 \%$ \\
\hline Tanzania & Labor Force Survey & 2014 & 396 & $12 \%$ & $1.4 \%$ \\
\hline Uganda & Living Standards Measurement Survey & 2013 & 170 & $15 \%$ & $2.6 \%$ \\
\hline Zambia & Labor Force Survey & 2014 & 486 & $10 \%$ & $2.4 \%$ \\
\hline \multicolumn{6}{|l|}{ Panel B: Comparator countries } \\
\hline Cambodia & Socio-Economic Survey & 2014 & 393 & $3 \%$ & $1 \%$ \\
\hline Indonesia & Labor Force Survey & 2015 & 12,077 & $11 \%$ & $4 \%$ \\
\hline Pakistan & Labor Force Survey & $2014-2015$ & 2,159 & $15 \%$ & $3 \%$ \\
\hline Bolivia & Household Income Survey & 2015 & 403 & $6 \%$ & $2 \%$ \\
\hline Mexico & Household Income Survey & 2016 & 1,533 & $4 \%$ & $1 \%$ \\
\hline
\end{tabular}

Notes: The surveys in African countries are available from the World Bank Microdata Library. The Cambodian Socio-Economic Survey is available from the Microdata Library of the National Institute of Statistics of Cambodia. The Indonesian Labor Force Survey is available from the ILO Microdata Repository. The Pakistani Labor Force Survey is available upon request from the Pakistan Bureau of Statistics. The Bolivian Household Income Survey is available from The Mexican Household Income Survey is available from the database of National Institute of Statistics and Geography (INEGI). 
Table 2. Demographic characteristics of teachers

\begin{tabular}{|c|c|c|c|c|c|c|c|c|}
\hline \multirow[b]{2}{*}{ Country } & \multirow{2}{*}{$\begin{array}{c}\text { Teachers } \\
\text { Age }\end{array}$} & \multicolumn{7}{|c|}{ Other wage workers } \\
\hline & & $\begin{array}{l}\text { Percent } \\
\text { male }\end{array}$ & $\begin{array}{c}\text { Percent } \\
\text { urban }\end{array}$ & $\begin{array}{l}\text { Percent working in } \\
\text { private schools }\end{array}$ & $\begin{array}{l}\text { Percent on fixed } \\
\text { term/temporary } \\
\text { contracts }\end{array}$ & Age & $\begin{array}{l}\text { Percent } \\
\text { male }\end{array}$ & $\begin{array}{c}\text { Percent } \\
\text { urban }\end{array}$ \\
\hline \multicolumn{9}{|c|}{ African countries } \\
\hline Burkina Faso & 35.1 & $57.3 \%$ & $76.6 \%$ & $20.4 \%$ & $10.6 \%$ & 33.0 & $73.1 \%$ & $79.6 \%$ \\
\hline Côte d'Ivoire & 38.4 & $79.1 \%$ & $76.1 \%$ & $21.0 \%$ & $41.7 \%$ & 33.5 & $75.7 \%$ & $80.1 \%$ \\
\hline DR Congo & 37.5 & $72.6 \%$ & $50.6 \%$ & $15.1 \%$ & $40.0 \%$ & 39.7 & $78.8 \%$ & $81.2 \%$ \\
\hline The Gambia & 35.2 & $67.5 \%$ & $67.5 \%$ & $38.3 \%$ & - & 33.6 & $71.7 \%$ & $79.6 \%$ \\
\hline Ghana & 35.0 & $64.6 \%$ & $61.4 \%$ & $17.9 \%$ & - & 35.9 & $70.6 \%$ & $74.7 \%$ \\
\hline Liberia & 44.6 & $85.4 \%$ & $42.1 \%$ & $29.4 \%$ & - & 38.1 & $80.0 \%$ & $58.4 \%$ \\
\hline Malawi & 38.2 & $59.5 \%$ & $41.2 \%$ & $21.9 \%$ & - & 34.7 & $79.2 \%$ & $47.6 \%$ \\
\hline Namibia & 39.7 & $34.9 \%$ & $48.7 \%$ & $4.7 \%$ & $14.9 \%$ & 35.9 & $57.8 \%$ & $78.2 \%$ \\
\hline Niger & 37.2 & $47.9 \%$ & $90.6 \%$ & $18.0 \%$ & $29.1 \%$ & 36.2 & $85.0 \%$ & $78.2 \%$ \\
\hline Nigeria & 40.7 & $45.4 \%$ & $45.4 \%$ & $24.2 \%$ & - & 39.6 & $68.1 \%$ & $54.2 \%$ \\
\hline Senegal & 37.1 & $76.7 \%$ & $83.4 \%$ & $9.1 \%$ & $16.9 \%$ & 35.6 & $64.6 \%$ & $82.0 \%$ \\
\hline Sierra Leone & 41.8 & $63.6 \%$ & $79.3 \%$ & $25.5 \%$ & $16.9 \%$ & 38.8 & $69.0 \%$ & $90.4 \%$ \\
\hline Tanzania & 38.6 & $43.9 \%$ & $85.4 \%$ & $19.3 \%$ & $5.4 \%$ & 37.5 & $70.7 \%$ & $96.3 \%$ \\
\hline Uganda & 37.5 & $60.6 \%$ & $29.4 \%$ & $31.2 \%$ & $40.1 \%$ & 31.9 & $71.5 \%$ & $48.8 \%$ \\
\hline Zambia & 35.3 & $49.6 \%$ & $60.1 \%$ & $12.1 \%$ & $12.6 \%$ & 33.1 & $73.1 \%$ & $69.3 \%$ \\
\hline Average & 38.1 & $60.6 \%$ & $62.5 \%$ & $20.5 \%$ & $22.3 \%$ & 35.8 & $72.6 \%$ & $73.2 \%$ \\
\hline \multicolumn{9}{|c|}{ Comparator countries } \\
\hline Cambodia & 38.0 & $51.1 \%$ & $46.3 \%$ & $5.9 \%$ & - & 31.0 & $56.9 \%$ & $41.5 \%$ \\
\hline Indonesia & 40.4 & $38.9 \%$ & $38.9 \%$ & - & - & 35.9 & $69.4 \%$ & $65.8 \%$ \\
\hline Pakistan & 36.4 & $74.2 \%$ & $45.0 \%$ & $29.9 \%$ & $7.7 \%$ & 34.8 & $65.2 \%$ & $53.7 \%$ \\
\hline Bolivia & 42.0 & $38.5 \%$ & $87.6 \%$ & $9.8 \%$ & - & 33.9 & $67.2 \%$ & $89.0 \%$ \\
\hline Mexico & 39.3 & $40.3 \%$ & $80.1 \%$ & $12.2 \%$ & $15.6 \%$ & 35.9 & $62.8 \%$ & $78.8 \%$ \\
\hline Average & 39.2 & $48.6 \%$ & $59.6 \%$ & $14.4 \%$ & $11.7 \%$ & 34.3 & $64.3 \%$ & $65.8 \%$ \\
\hline
\end{tabular}

Notes: Data in The Gambia, Ghana, Liberia, Malawi, Nigeria, Malawi, Cambodia and do not report a worker's contract type.

Source: Surveys listed in Table 1. Several countries do not ask the question of whether workers are on permanent or fixed-term contracts. 
Table 3. Educational attainment of teachers and other wage workers (percentage of teachers)

\begin{tabular}{|c|c|c|c|c|c|c|c|c|c|c|c|c|}
\hline \multirow[b]{2}{*}{ Country } & \multicolumn{3}{|c|}{ Teachers } & \multicolumn{3}{|c|}{ Other wage workers } & \multicolumn{3}{|c|}{ Primary teachers } & \multicolumn{3}{|c|}{ Secondary teachers } \\
\hline & $\mathbf{P}$ & $\mathbf{S}$ & P-S & $\mathbf{P}$ & $\mathrm{S}$ & P-S & $\mathbf{P}$ & $\mathbf{S}$ & P-S & $\mathbf{P}$ & S & P-S \\
\hline \multicolumn{13}{|c|}{ African countries } \\
\hline Burkina Faso & 6.1 & 73.1 & 20.8 & 59.3 & 31.8 & 8.9 & 7.1 & 82.7 & 10.2 & 0.0 & 12.8 & 87.2 \\
\hline Côte d'Ivoire & 13.5 & 2.5 & 84.0 & 73.5 & 1.7 & 24.8 & 18.7 & 2.4 & 78.9 & 5.2 & 2.6 & 92.2 \\
\hline DR Congo & 2.5 & 82.7 & 14.8 & 17.0 & 56.4 & 26.6 & 2.6 & 86.6 & 10.8 & 1.8 & 62.0 & 36.3 \\
\hline The Gambia & 5.8 & 36.7 & 57.5 & 41.5 & 47.2 & 11.4 & 9.8 & 42.7 & 47.6 & 0.0 & 27.8 & 72.2 \\
\hline Ghana & 0.4 & 26.0 & 73.5 & 22.5 & 54.5 & 23.0 & 0.5 & 35.8 & 63.7 & 0.3 & 13.0 & 86.7 \\
\hline Liberia & 1.9 & 76.9 & 21.2 & 39.7 & 49.8 & 10.5 & 2.3 & 85.2 & 12.5 & 0.0 & 39.3 & 60.7 \\
\hline Malawi & 5.1 & 65.1 & 29.8 & 52.9 & 36.4 & 10.7 & \multicolumn{6}{|c|}{ N.A. } \\
\hline Namibia & 1.1 & 30.1 & 68.8 & 18.4 & 68.0 & 13.6 & 0.5 & 39.0 & 60.5 & 2.2 & 15.4 & 82.4 \\
\hline Niger & 4.2 & 67.2 & 28.6 & 61.4 & 27.8 & 10.8 & 5.4 & 79.6 & 15.1 & 0.0 & 23.1 & 76.9 \\
\hline Nigeria & 1.7 & 10.8 & 87.5 & 18.5 & 40.1 & 41.4 & 1.9 & 15.5 & 82.6 & 1.3 & 1.3 & 97.5 \\
\hline Senegal & 2.2 & 48.5 & 49.4 & 57.3 & 33.6 & 9.2 & 3.4 & 75.3 & 21.4 & 0.7 & 15.8 & 83.6 \\
\hline Sierra Leone & 1.8 & 22.5 & 75.7 & 16.6 & 50.9 & 32.5 & 2.3 & 26.2 & 71.5 & 1.1 & 17.1 & 81.8 \\
\hline Tanzania & 0.3 & 34.9 & 64.9 & 39.6 & 36.8 & 23.6 & 0.4 & 44.2 & 55.4 & 0.0 & 12.7 & 87.3 \\
\hline Uganda & 0.6 & 7.2 & 92.2 & 54.4 & 26.3 & 19.3 & 0.7 & 7.9 & 91.4 & 0.0 & 3.9 & 96.2 \\
\hline Zambia & 15.8 & 64.8 & 19.4 & 17.4 & 68.9 & 13.6 & 0.9 & 30.2 & 68.9 & 0.0 & 23.1 & 76.9 \\
\hline Average & 4.2 & 43.3 & 52.5 & 39.3 & 42.0 & 18.7 & 4.0 & 46.7 & 49.3 & 0.9 & 19.3 & 79.8 \\
\hline \multicolumn{13}{|c|}{ Comparator countries } \\
\hline Cambodia & 4.0 & 15.7 & 80.3 & 44.6 & 28.5 & 26.9 & 4.8 & 25.0 & 70.2 & 3.1 & 4.9 & 92.0 \\
\hline Indonesia & 0.2 & 12.1 & 87.7 & 24.0 & 57.2 & 18.9 & 0.2 & 16.9 & 82.9 & 0.1 & 5.8 & 94.2 \\
\hline Pakistan & 1.4 & 31.5 & 67.1 & 36.0 & 45.7 & 18.3 & 0.4 & 43.0 & 56.6 & 3.1 & 13.3 & 83.7 \\
\hline Mexico & 0.1 & 4.6 & 95.2 & 11.6 & 55.8 & 32.6 & 0.2 & 4.7 & 95.2 & 0.0 & 4.6 & 95.4 \\
\hline Bolivia & 0.0 & 1.5 & 98.5 & 15.9 & 46.6 & 37.6 & 0.0 & 1.6 & 98.4 & 0.0 & 0.6 & 99.4 \\
\hline Average & 1.1 & 13.1 & 85.8 & 26.4 & 46.6 & 26.8 & 1.1 & 18.2 & 80.6 & 1.3 & 5.8 & 92.9 \\
\hline
\end{tabular}

Notes: P stands for primary school education. S stands for secondary school education. P-S stands for post-secondary school education. The number in each cell represents the proportion of teachers with each level of education. Source: Surveys listed in Table 1. 
Table 4. Teacher average working hours and median earnings

\begin{tabular}{|c|c|c|c|c|c|c|c|c|c|c|}
\hline & \multicolumn{2}{|c|}{$\begin{array}{c}\text { Monthly earnings in PPP } \\
(\$)\end{array}$} & \multicolumn{2}{|c|}{$\begin{array}{c}\text { Monthly earnings relative } \\
\text { to GDP per capita }\end{array}$} & \multicolumn{2}{|c|}{$\begin{array}{c}\text { Hourly earnings in PPP } \\
(\$)\end{array}$} & \multicolumn{2}{|c|}{ Hours worked weekly } & \multicolumn{2}{|c|}{$\begin{array}{c}\text { Percent of having a } \\
\text { second job }\end{array}$} \\
\hline & Teacher & Other workers & Teacher & Other workers & Teacher & Other workers & Teacher & Other workers & Teacher & Other workers \\
\hline \multicolumn{11}{|c|}{ African countries } \\
\hline Burkina Faso & 626 & 232 & 4.6 & 1.7 & 4.0 & 1.3 & 39 & 52 & $22.3 \%$ & $25.9 \% \mathrm{z}$ \\
\hline Côte d'Ivoire & 898 & 339 & 3.6 & 1.4 & 6.6 & 2.1 & 32 & 46 & $15.9 \%$ & $13.2 \%$ \\
\hline DR Congo & 100 & 114 & 1.5 & 1.8 & 0.7 & 0.7 & 34 & 45 & $46.9 \%$ & $22.9 \%$ \\
\hline The Gambia & 265 & 235 & 2.0 & 1.8 & - & - & - & - & - & - \\
\hline Ghana & 644 & 389 & 2.0 & 1.2 & 4.4 & 2.1 & 34 & 50 & $26.9 \%$ & $14.9 \%$ \\
\hline Liberia & 220 & 278 & 3.1 & 3.9 & 1.7 & 1.5 & 33 & 52 & $5.8 \%$ & $3.8 \%$ \\
\hline Malawi & 338 & 257 & 4.0 & 3.0 & 2.6 & 1.8 & 33 & 43 & $3.3 \%$ & $1.2 \%$ \\
\hline Namibia & 2,306 & 633 & 2.9 & 0.8 & 14.7 & 3.4 & 39 & 50 & $6.5 \%$ & $3.3 \%$ \\
\hline Niger & 400 & 533 & 5.1 & 6.8 & 2.8 & 3.0 & 34 & 45 & $15.4 \%$ & $8.9 \%$ \\
\hline Nigeria & 460 & 460 & 0.9 & 0.9 & 2.9 & 2.8 & 39 & 46 & $2.1 \%$ & $1.1 \%$ \\
\hline Senegal & 819 & 647 & 4.6 & 3.6 & 5.6 & 3.2 & 35 & 48 & $14.8 \%$ & $8.7 \%$ \\
\hline Sierra Leone & 334 & 353 & 2.2 & 2.4 & 2.8 & 1.8 & 31 & 50 & $21.2 \%$ & $8.1 \%$ \\
\hline Tanzania & 805 & 773 & 3.8 & 3.7 & 5.0 & 3.9 & 42 & 54 & $22.5 \%$ & $7.6 \%$ \\
\hline Uganda & 323 & 296 & 2.3 & 2.1 & 2.1 & 1.5 & 39 & 50 & $47.1 \%$ & $20.9 \%$ \\
\hline Zambia & 1,639 & 465 & 5.1 & 1.5 & 10.7 & 2.3 & 39 & 50 & $10.1 \%$ & $5.2 \%$ \\
\hline Average & 679 & 400 & 3.2 & 2.4 & 4.4 & 2.1 & 36 & 49 & $18.6 \%$ & $10.4 \%$ \\
\hline \multicolumn{11}{|c|}{ Comparator countries } \\
\hline Cambodia & 418 & 445 & 1.5 & 1.6 & 2.5 & 2.0 & 45 & 54 & $37.2 \%$ & $10.6 \%$ \\
\hline Indonesia & 667 & 420 & 0.7 & 0.5 & 4.2 & 2.2 & 34 & 44 & - & - \\
\hline Pakistan & 835 & 640 & 2.1 & 1.6 & 5.3 & 3.1 & 39 & 50 & $9.8 \%$ & $4.1 \%$ \\
\hline Bolivia & 1,199 & 883 & 2.1 & 1.5 & 11.4 & 4.8 & 27 & 47 & $12.7 \%$ & $5.4 \%$ \\
\hline Mexico & 1,157 & 770 & 0.8 & 0.5 & 9.7 & 4.0 & 32 & 50 & $9.7 \%$ & $5.7 \%$ \\
\hline Average & 855 & 632 & 1.4 & 1.1 & 6.6 & 3.2 & 35 & 49 & $17.3 \%$ & $6.4 \%$ \\
\hline
\end{tabular}

Notes: All the earnings are in PPP $(\$, 2011)$. Other workers refer to wage workers except for teachers. Both the teacher sample and other wage workers sample only include workers with secondary or post-secondary education.

Source: Surveys listed in Table 1. 
Table 5A. Monthly median earnings for workers with secondary education by occupation group

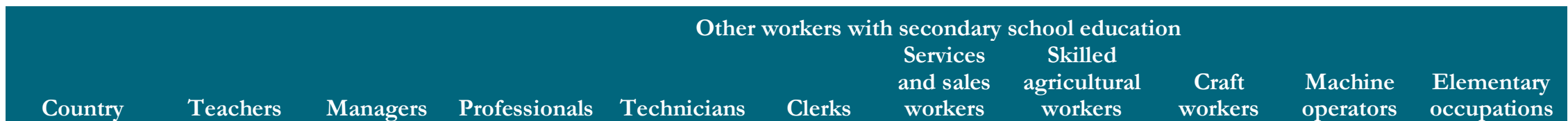

\begin{tabular}{|c|c|c|c|c|c|c|c|c|c|c|}
\hline \multicolumn{11}{|c|}{ African countries } \\
\hline Burkina Faso & 580 & 603 & 777 & 464 & 441 & 200 & 172 & 181 & - & - \\
\hline Côte d'Ivoire & 975 & 498 & 699 & 847 & 841 & 309 & - & 407 & 424 & 212 \\
\hline DR Congo & 96 & 100 & 91 & 91 & 102 & 109 & 91 & 154 & 182 & 112 \\
\hline The Gambia & 254 & 400 & 265 & 273 & 235 & 204 & 255 & 204 & 204 & 153 \\
\hline Ghana & 278 & 556 & 389 & 367 & 333 & 222 & 194 & 339 & 333 & 233 \\
\hline Liberia & 211 & 431 & 237 & 279 & 306 & 222 & 278 & 296 & 301 & 176 \\
\hline Malawi & 294 & 544 & 243 & - & 254 & 147 & 176 & 235 & 235 & 180 \\
\hline Namibia & 1,447 & 1,537 & 1,265 & 1,009 & 723 & 362 & 330 & 542 & 814 & 362 \\
\hline Niger & 349 & 889 & 267 & 886 & 544 & 336 & 273 & 367 & - & - \\
\hline Nigeria & 230 & 402 & 259 & 253 & 368 & 172 & 92 & 460 & 459 & 239 \\
\hline Senegal & 688 & 1,034 & 690 & 739 & 647 & 345 & 334 & 371 & 323 & 194 \\
\hline Sierra Leone & 288 & 222 & 356 & 319 & 323 & 289 & - & 278 & 278 & 222 \\
\hline Tanzania & 724 & 724 & - & 757 & 600 & 563 & 402 & 644 & 584 & 394 \\
\hline Uganda & 188 & 494 & 395 & 491 & 79 & 166 & 197 & 232 & 286 & 158 \\
\hline Zambia & 1,610 & 1,073 & 1,646 & 1,073 & 716 & 304 & 206 & 465 & 465 & 233 \\
\hline Average & 547 & 634 & 541 & 561 & 434 & 263 & 231 & 345 & 376 & 221 \\
\hline \multicolumn{11}{|c|}{ Comparator countries } \\
\hline Cambodia & 401 & 427 & 460 & 504 & 445 & 356 & 415 & 415 & 445 & 371 \\
\hline Indonesia & 297 & 494 & 494 & 592 & 445 & 297 & 311 & 346 & 408 & 395 \\
\hline Pakistan & 748 & 960 & 558 & 640 & 711 & 462 & 471 & 198 & 462 & 462 \\
\hline Bolivia & 840 & 954 & 1,014 & 856 & 752 & 602 & 613 & 850 & 998 & 680 \\
\hline Mexico & 607 & 1,335 & 992 & - & 685 & 616 & 566 & 729 & 660 & 560 \\
\hline Average & 579 & 834 & 704 & 648 & 608 & 467 & 475 & 508 & 595 & 494 \\
\hline
\end{tabular}

Notes: All the earnings are in PPP (\$,2011). ISCO-08 group definitions are used to classify occupations (ILO, 2012). Elementary occupations involve the performance of simple and routine tasks which may require the use of hand-held tools and considerable physical effort. Earnings in italics are estimated based on fewer than 10 observations. Sample only includes workers with secondary or post-secondary education.

Source: Surveys listed in Table 1. 
Table 5B. Monthly median earnings for workers with post-secondary education by occupation group

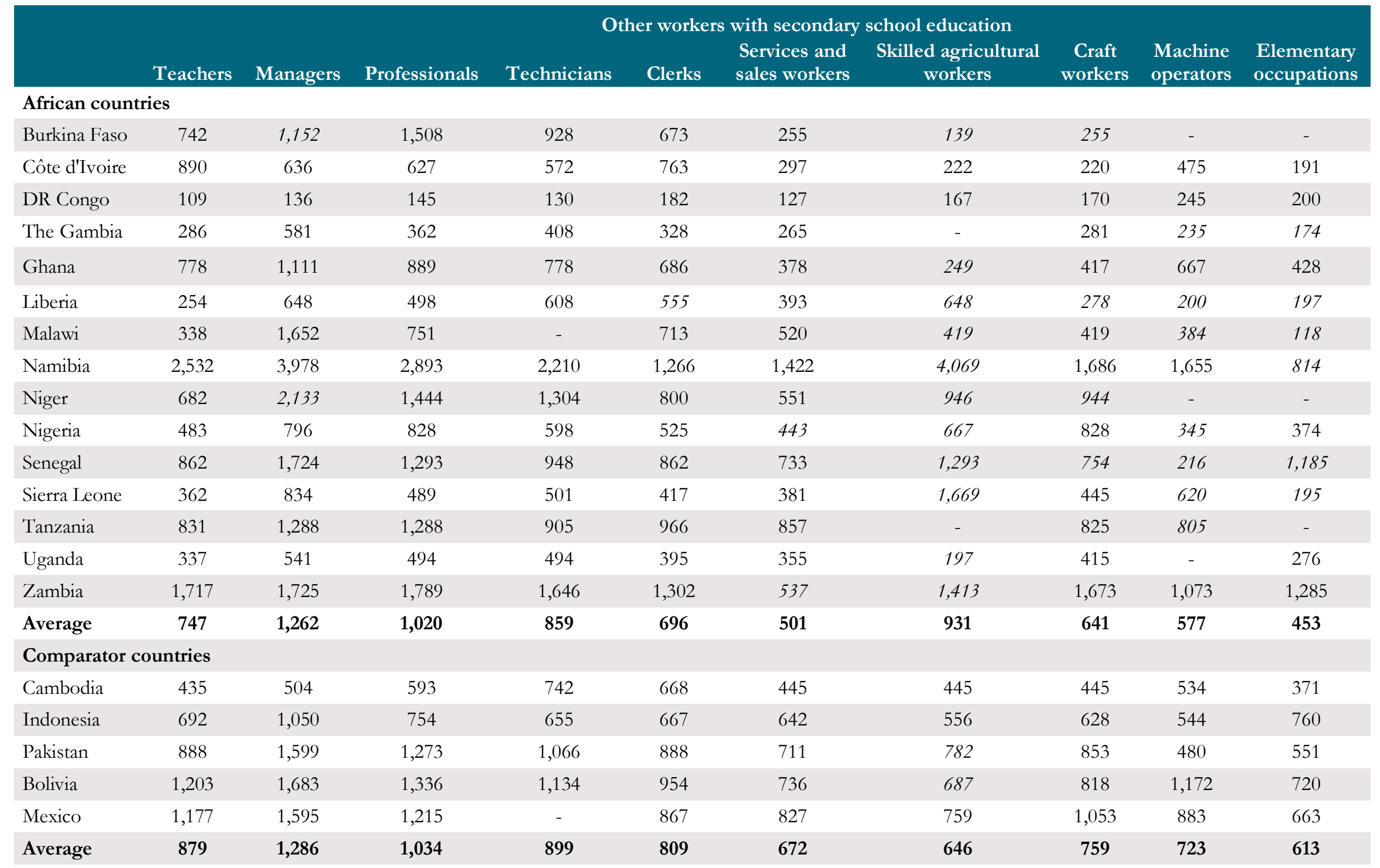

Notes: Earnings are in PPP (\$,2011). ISCO-08 group definitions are used to classify occupations (ILO, 2012). Elementary occupations involve the performance of simple and routine tasks which may require the use of hand-held tools and considerable physical effort. Earnings in italics are estimated based on fewer than 10 observations. Sample only includes workers with secondary or post-secondary education. Source: Surveys listed in Table 1. 
Table 6. Comparison of teacher monthly earnings by contract type

\begin{tabular}{|c|c|c|c|c|c|c|c|c|c|c|c|}
\hline \multirow{2}{*}{\multicolumn{2}{|c|}{ Median }} & \multicolumn{4}{|c|}{ Teachers on a permanent contract } & \multicolumn{5}{|c|}{ Teachers on a fixed term/temporary contract } & \multirow[b]{2}{*}{$\begin{array}{l}\text { Ratio of } \\
\text { medians }\end{array}$} \\
\hline & & $\begin{array}{l}\text { Standard } \\
\text { deviation }\end{array}$ & $\begin{array}{l}\text { Inter- } \\
\text { quartile }\end{array}$ & $\begin{array}{c}\text { Inter- } \\
\text { quartile/mean }\end{array}$ & $\mathbf{N}$ & Median & $\begin{array}{l}\text { Standard } \\
\text { deviation }\end{array}$ & $\begin{array}{c}\text { Inter- } \\
\text { quartile }\end{array}$ & $\begin{array}{c}\text { Inter- } \\
\text { quartile/mean }\end{array}$ & $\mathbf{N}$ & \\
\hline \multicolumn{12}{|c|}{ African countries } \\
\hline Burkina Faso & 650 & 737 & 557 & 0.89 & 262 & 232 & 465 & 664 & 1.43 & 31 & 0.36 \\
\hline Côte d'Ivoire & 1,081 & 650 & 614 & 0.54 & 49 & 360 & 422 & 657 & 1.25 & 35 & 0.33 \\
\hline DR Congo & 100 & 62 & 16 & 0.16 & 515 & 91 & 59 & 42 & 0.45 & 344 & 0.91 \\
\hline The Gambia & - & - & - & - & - & - & - & - & - & - & - \\
\hline Ghana & - & - & - & - & - & - & - & - & - & - & - \\
\hline Liberia & - & - & - & - & - & - & - & - & - & - & - \\
\hline Malawi & - & - & - & - & - & - & - & - & - & - & - \\
\hline Namibia & 2,351 & 877 & 1,040 & 0.46 & 291 & 1,627 & 988 & 1,606 & 0.93 & 51 & 0.69 \\
\hline Niger & 555 & 1,925 & 554 & 0.56 & 83 & 334 & 184 & 56 & 0.16 & 34 & 0.60 \\
\hline Nigeria & - & - & - & - & - & - & - & - & - & - & - \\
\hline Senegal & 2,264 & 4,699 & 1,149 & 0.36 & 260 & 1,781 & 4,661 & 1,034 & 0.32 & 53 & 0.79 \\
\hline Sierra Leone & 334 & 7,230 & 206 & 0.13 & 260 & 363 & 11,012 & 195 & 0.05 & 53 & 1.09 \\
\hline Tanzania & 805 & 370 & 407 & 0.47 & 366 & 713 & 679 & 459 & 0.51 & 21 & 0.89 \\
\hline Uganda & 346 & 122 & 94 & 0.26 & 97 & 262 & 240 & 222 & 0.69 & 65 & 0.76 \\
\hline Zambia & 1,686 & 571 & 465 & 0.27 & 416 & 1,413 & 751 & 1,324 & 1.11 & 60 & 0.84 \\
\hline Average & 1,017 & 1,724 & 510 & 0.41 & 260 & 718 & 1,946 & 626 & 0.69 & 75 & 0.71 \\
\hline \multicolumn{12}{|c|}{ Comparator countries } \\
\hline Cambodia & - & - & - & - & - & - & - & - & - & - & - \\
\hline Indonesia & - & - & - & - & - & - & - & - & - & - & - \\
\hline Pakistan & 995 & 443 & 494 & 0.48 & 1,358 & 355 & 365 & 462 & 1.00 & 114 & 0.36 \\
\hline Bolivia & - & - & - & - & - & - & - & - & - & - & - \\
\hline Mexico & 1,223 & 565 & 650 & 0.49 & 1,280 & 739 & 449 & 692 & 0.94 & 236 & 0.60 \\
\hline Average & 1,109 & 504 & 572 & 0.48 & 1,319 & 547 & 407 & 577 & 0.97 & 175 & 0.49 \\
\hline
\end{tabular}

Notes: Earnings are in PPP $(\$, 2011)$. Ratio of medians is the ratio of the median earnings for teachers on a fixed term or temporary contract to that for teachers on a permanent contract. Sample includes teachers with secondary or post-secondary education. Hourly earnings are not available for The Gambia. Data in The Gambia, Ghana, Liberia, Malawi, Nigeria, Malawi, Cambodia and do not report a worker's contract type.

Source: Surveys listed in Table 1. 
Table 7. Comparison of teacher hourly earnings by contract type

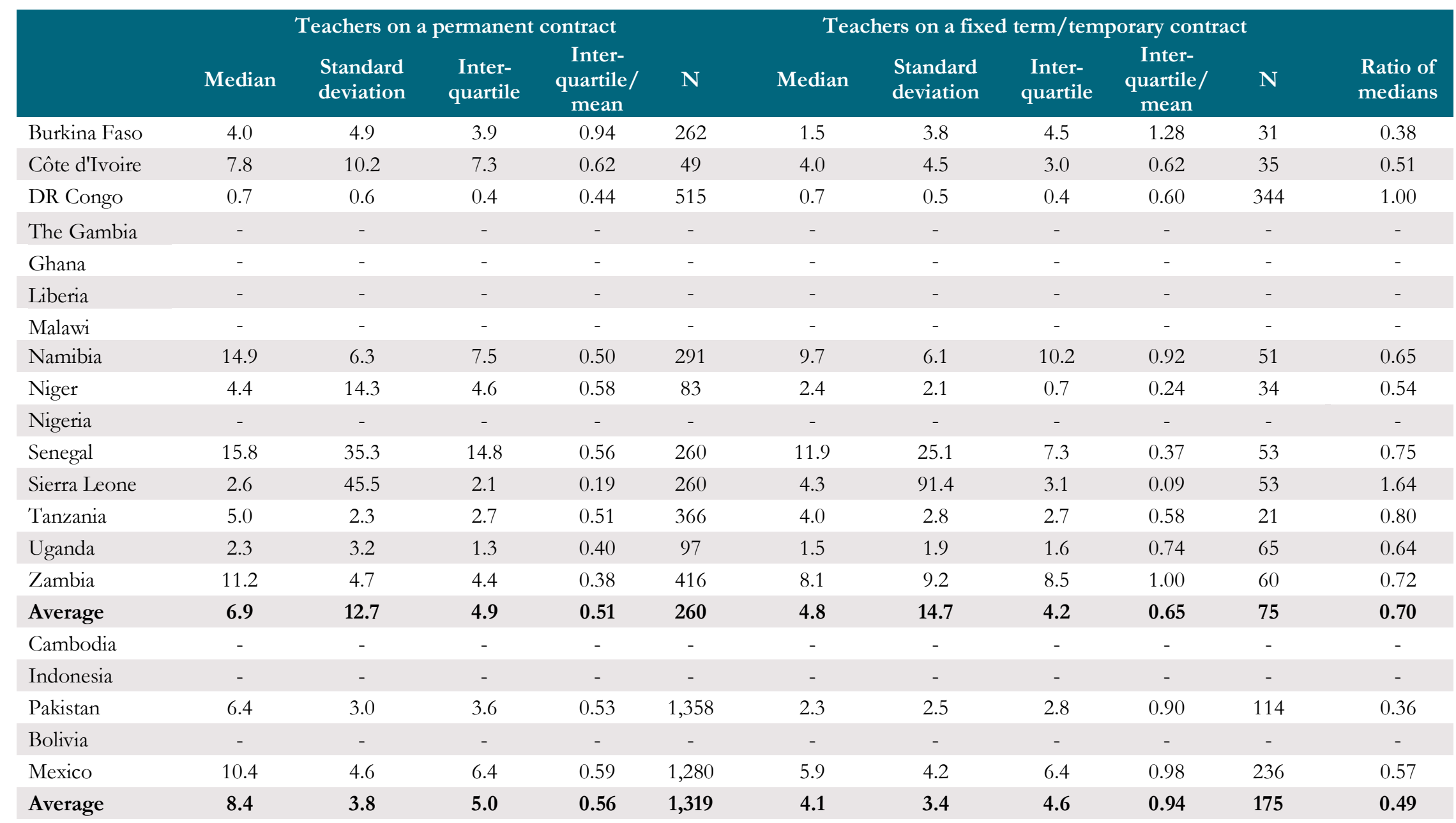

Notes: Earnings are in PPP (\$,2011). Ratio of medians is the ratio of the median earnings for teachers on a fixed term or temporary contract to that for teachers on a permanent contract. Sample includes teachers with secondary or post-secondary education. Hourly earnings are not available for The Gambia. Data in The Gambia, Ghana, Liberia, Malawi, Nigeria, Malawi, Cambodia and do not report a worker's contract type.

Source: Surveys listed in Table 1. 
Table 8. Monthly earnings differentials between teachers and other wage workers

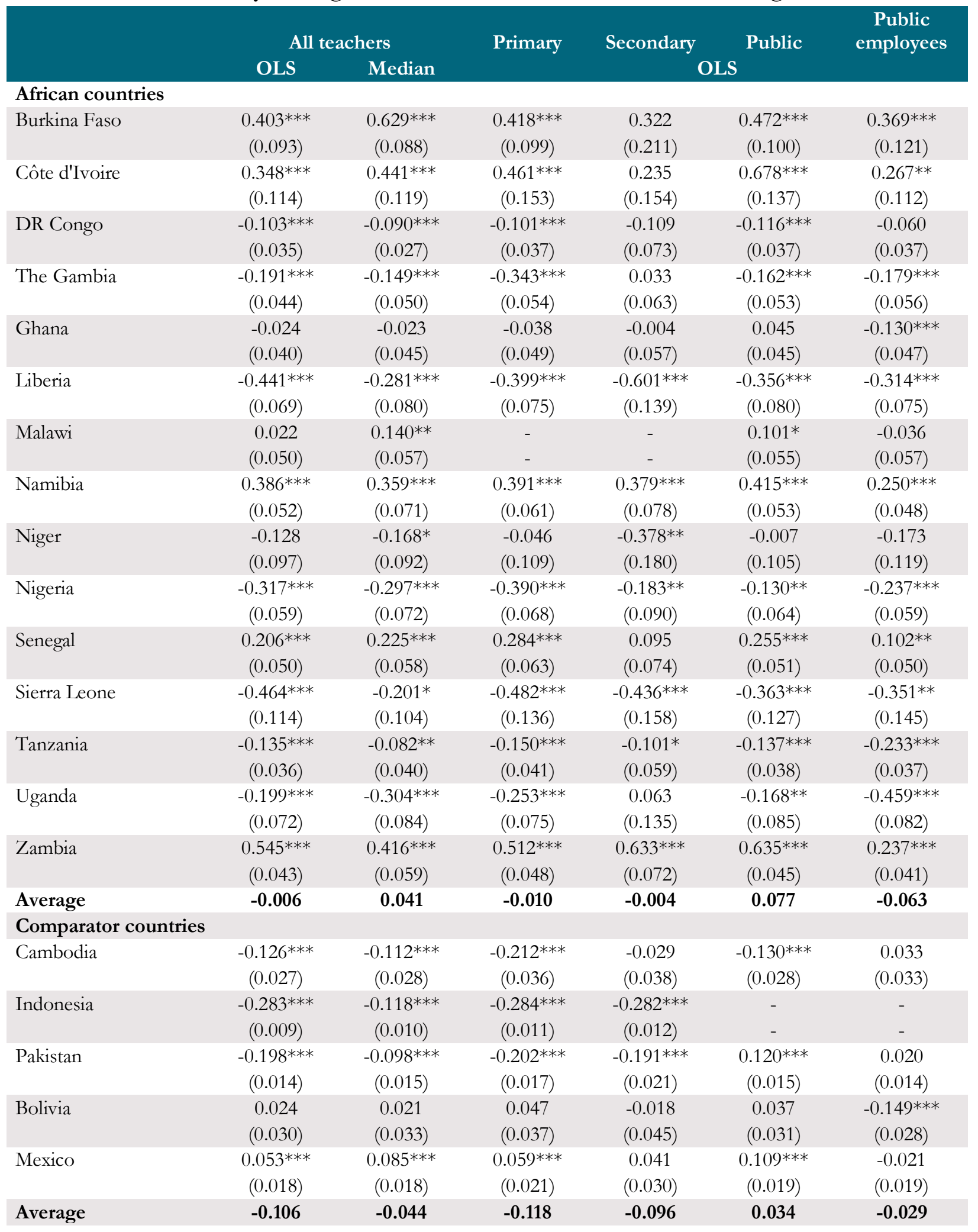

Notes: Each column reports the coefficient in the regressions of $\ln$ (monthly earnings) on (a dummy for) a type of teachers with controls. The comparison group are other wage workers. Controls include gender, age, age-squared, urbanicity and (a dummy for) post-secondary education. The last column reports the coefficients of teacher earnings premiums with the comparison group being other public sector employees. Standard errors in parentheses. ${ }^{* *} \mathrm{p}<0.01,{ }^{* *} \mathrm{p}<0.05,{ }^{*} \mathrm{p}<0.1$.

Source: Surveys listed in Table 1. 
Table 9. Hourly earnings differentials between teachers and other wage workers

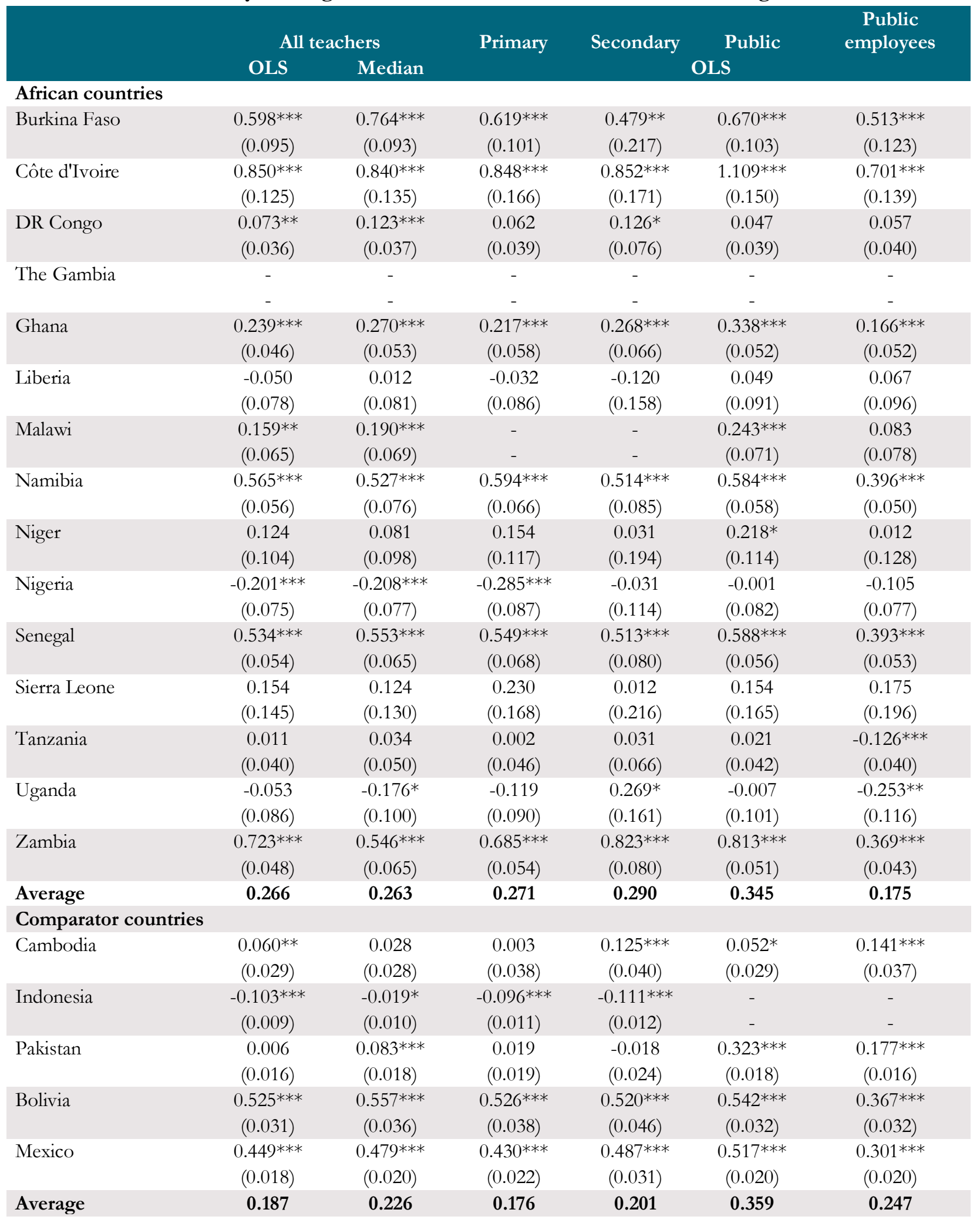

Notes: Each column reports the coefficient in the regressions of ln (hourly earnings) on (a dummy for) a type of teachers with controls. The comparison group are other wage workers. Controls include gender, age, age-squared, urbanicity and (a dummy for) post-secondary education. The last column reports the coefficients of teacher earnings premiums with the comparison group being other public sector employees. Standard errors in parentheses. ${ }^{* *} \mathrm{p}<0.01,{ }^{* *} \mathrm{p}<0.05,{ }^{*} \mathrm{p}<0.1$.

Source: Surveys listed in Table 1. 
Table 10. Earnings differentials between teachers and other wage workers by contract type

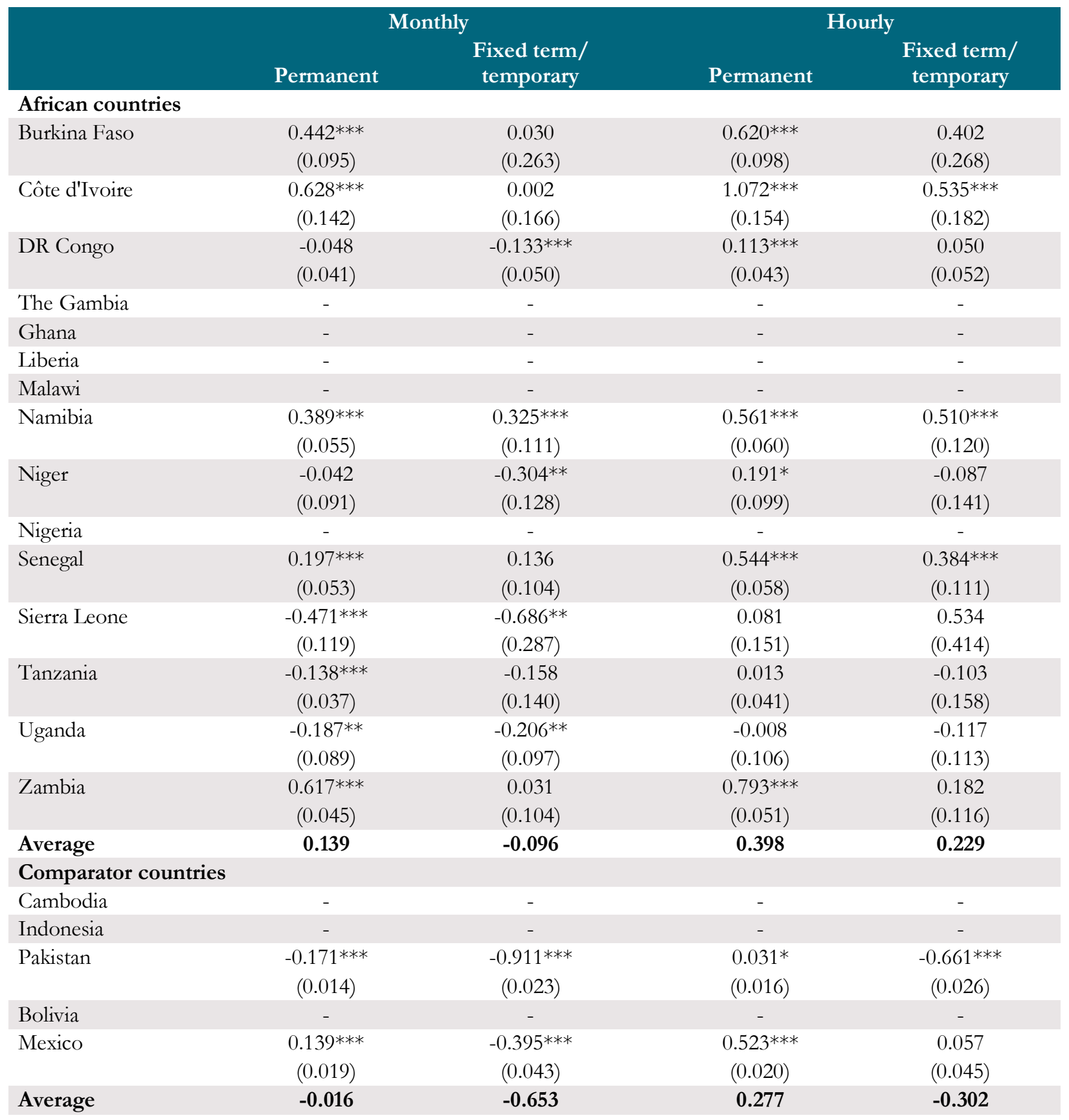

Notes: Each column reports the coefficient in the regressions of $\ln$ (monthly/hourly earnings) on (a dummy for) a type of teachers with controls. The comparison group are other wage workers. Controls include gender, age, age-squared, urbanicity and (a dummy for) post-secondary education. Hourly earnings are not available for The Gambia. Data in The Gambia, Ghana, Liberia, Malawi, Nigeria, Malawi, Cambodia and Indonesia do not report a worker's contract type. Standard errors in parentheses. ${ }^{* *} \mathrm{p}<0.01,{ }^{* *}$ $\mathrm{p}<0.05,{ }^{*} \mathrm{p}<0.1$.

Source: Surveys listed in Table 1. 
Table 11. Teacher earnings differential and student performance

\begin{tabular}{|c|c|c|}
\hline & Harmonized test score & Learning poverty \\
\hline \multirow[t]{2}{*}{ Monthly earnings differential } & $97.95^{* *}$ & -0.13 \\
\hline & (36.13) & $(0.20)$ \\
\hline \multirow[t]{2}{*}{ African country dummy } & $-57.11 * *$ & $0.37 * * *$ \\
\hline & $(25.14)$ & $(0.09)$ \\
\hline Countries & 19 & 10 \\
\hline Adj. R2 & 0.32 & 0.63 \\
\hline \multirow[t]{2}{*}{ Hourly earnings differential } & $75.72 *$ & -0.10 \\
\hline & $(38.83)$ & $(0.14)$ \\
\hline \multirow[t]{2}{*}{ African country dummy } & $-53.71 *$ & $0.36^{* * *}$ \\
\hline & $(28.23)$ & $(0.09)$ \\
\hline Countries & 18 & 10 \\
\hline Adj. R2 & 0.2 & 0.63 \\
\hline
\end{tabular}

Notes: Each column represents a regression of test scores (harmonized test scores or learning poverty) on earnings differentials. Africa country dummy denotes whether a country is in our African sample. Standard errors in parentheses. ${ }^{* * *} \mathrm{p}<0.01,{ }^{* *} \mathrm{p}<0.05, *$ $\mathrm{p}<0.1$

Source: Harmonized test scores from Human Capital Index. Data is not available for Bolivia. Learning poverty data from the World Bank (2019a). Earnings differentials from survey data listed in Table 1. 


\section{Appendix 1: Teacher earnings and student performance}

We use two approaches to explore the association between teacher salaries and student performance-first a cross-country approach building on our estimates, second a within-country approach using PASEC microdata from 10 African countries. ${ }^{26}$

\section{Cross-country}

We carry out exploratory cross-country correlational analyses between teacher earnings differentials and other observed variables. Specifically, we examine the association with student achievement using two measures. The first measure of student achievement is the harmonized test scores from the Human Capital Index database, recently developed by the World Bank (2018a).27 This database harmonizes results from international and regional testing programs to make student achievement comparable across nearly 160 countries and economies in the world, and it covers all countries in our sample. The harmonized test scores range from 300 to 600 points and are expressed in the unit of the Trends in International Mathematics and Science Study (TIMSS) testing program. The average score across countries is 431 points, with a standard deviation of 69 points.

Second, we use the rate of "learning poverty" defined as the share of children who are unable to read and understand a simple text by age 10 (World Bank, 2019a). The learning poverty indicator takes into account both the minimum reading proficiency of children in school as well as the proportion of children who are out of school. Compared to the Human Capital Index measure, the learning poverty measure captures a fuller view of student achievement (with its accounting for out-of-school children), but its data coverage is less comprehensive. Among the countries in our sample, only six African countries and four comparator countries have learning poverty data.

\section{Within-country}

We complement this cross-country analysis with within country analysis of the relationship between teacher salaries and student test scores using PASEC microdata from 10 African countries. ${ }^{28}$ Specifically, for student $i$ with teacher $t$ we estimate a model that pools across countries and included fixed effects.

$$
\text { Test } \text { Score }_{i t}=\alpha+\beta * \ln (\text { Salary })_{t}+\text { Country }_{F E}+\varepsilon_{i t}(3)
$$

\footnotetext{
26 The mean and standard deviation of test scores for each grade level are reported in Table A4.

27 There are two regional testing programs in Sub-Saharan Africa: the Southern and Eastern Africa Consortium for Monitoring Educational Quality (SACMEQ) organizes the literacy and numeracy assessments of Grade 6 students in most Anglophone SubSaharan African countries; and the Analysis Programme of the CONFEMEN Education Systems (PASEC) leads assessments of Grade 6 students in Francophone Sub-Saharan African countries.

28 The mean and standard deviation of test scores for each grade level are reported in Table A4.
} 
We also estimate a model that includes a vector of controls $(\boldsymbol{X})$ for teacher characteristics: gender, experience and its square, years of schooling, highest education degree obtained, duration of preservice training, whether the teacher is also the principal, and contract status.

$$
\text { Test } \text { Score }_{i t}=\alpha+\beta * \ln (\text { Salary })_{t}+\delta * \boldsymbol{X}+\text { Country }_{F E}+\varepsilon_{i t}(4)
$$

Student and teacher data are collected in Grades 2 and 6 in the study countries. We estimate models that pool the data across grades (and in those models include a dummy variable for being a Grade 6 observation) as well as grade-specific models. Note that salaries are reported in the survey in intervals (e.g., "Between CFAF 15,000 and 29,000" "Between CFAF 30,000 and 59,000" ...) —with a total of 13 possible intervals. We assign the value of the midpoint of the reported interval to the teacher as their salary. ${ }^{29}$ The estimates derived from this analysis are reported in Table A12.

${ }^{29}$ For the lowest interval "Less than CFAF 14,000" we assign a value of 14,000. 


\section{Appendix Tables}

Table A1. Data processing notes

\begin{tabular}{|c|c|c|c|c|c|c|c|}
\hline Country & Source & Year & Occupation code type & Weekly hours reported & $\begin{array}{l}\text { Reported } \\
\text { income }\end{array}$ & $\begin{array}{c}\text { Reported } \\
\text { secondary } \\
\text { job }\end{array}$ & $\begin{array}{l}\text { Reported } \\
\text { employer }\end{array}$ \\
\hline Burkina Faso & Continuous Multisectoral Survey & 2014 & survey-specific , 4 digits & $\begin{array}{l}\text { From daily hours and } \\
\text { working days in a week }\end{array}$ & $\begin{array}{l}\text { Salary }+ \text { salary } \\
\text { period }\end{array}$ & Yes & Yes \\
\hline Côte d'Ivoire & National Employment Survey & 2013 & survey-specific , 3 digits & $\begin{array}{l}\text { From daily hours and } \\
\text { working days in a week }\end{array}$ & $\begin{array}{l}\text { Salary }+ \text { salary } \\
\text { period }\end{array}$ & Yes & Yes \\
\hline DR Congo & National Household Survey & 2012 & survey-specific , 3 digits & reported & Monthly & Yes & Yes \\
\hline The Gambia & Integrated Household Survey & 2010 & ISCO codes (4 digits) & Working hours not reported & $\begin{array}{l}\text { Salary }+ \text { salary } \\
\text { period }\end{array}$ & No & Yes \\
\hline Ghana & Ghana Living Standards Survey 6 & $2012-2013$ & ISCO codes (4 digits) & reported & $\begin{array}{l}\text { Salary }+ \text { salary } \\
\text { period }\end{array}$ & Yes & Yes \\
\hline Liberia & $\begin{array}{l}\text { Household Income and Expenditure } \\
\text { Survey }\end{array}$ & 2014-2015 & ISCO 08 code ( 4 digits) & reported & $\begin{array}{l}\text { Salary + salary } \\
\text { period }\end{array}$ & Yes & Yes \\
\hline Malawi & Integrated Household Panel Survey & 2010 & $\begin{array}{c}\text { survey-specific major groups } \\
, 2 \text { digit group }\end{array}$ & reported & $\begin{array}{l}\text { Salary }+ \text { salary } \\
\text { period }\end{array}$ & Yes & Yes \\
\hline Namibia & Labor Force Survey & 2013 & ISCO codes (4 digits) & reported & $\begin{array}{l}\text { Salary + salary } \\
\text { period }\end{array}$ & Yes & Yes \\
\hline Niger & $\begin{array}{l}\text { National Survey on Household Living } \\
\text { Conditions and Agriculture }\end{array}$ & 2014 & survey-specific , 4-digit & reported & $\begin{array}{l}\text { Salary }+ \text { salary } \\
\text { period }\end{array}$ & Yes & Yes \\
\hline Nigeria & General Household Survey & 2015 & ISCO codes (4 digits) & reported & $\begin{array}{l}\text { Salary }+ \text { salary } \\
\text { period }\end{array}$ & Yes & Yes \\
\hline Senegal & Poverty Monitoring Survey & 2010 & survey-specific , 3 digits & $\begin{array}{l}\text { reported (but both primary } \\
\text { and secondary jobs) }\end{array}$ & Montly & Yes & Yes \\
\hline Sierra Leone & Labor Force Survey & 2014 & ISCO codes (4 digits) & reported & $\begin{array}{l}\text { Salary }+ \text { salary } \\
\text { period }\end{array}$ & Yes & Yes \\
\hline Tanzania & Labor Force Survey & 2014 & $\begin{array}{c}\text { country-specific, TASCO (4 } \\
\text { digits) }\end{array}$ & reported & $\begin{array}{l}\text { Salary }+ \text { salary } \\
\text { period }\end{array}$ & Yes & Yes \\
\hline Uganda & Living Standards Measurement Survey & 2013 & ISCO codes , 4 digits & reported & $\begin{array}{l}\text { Salary }+ \text { salary } \\
\text { period }\end{array}$ & Yes & Yes \\
\hline Zambia & Labor Force Survey & 2014 & ISCO codes (4 digits) & $\begin{array}{l}\text { From daily hours and } \\
\text { working days in a week }\end{array}$ & $\begin{array}{l}\text { Salary }+ \text { salary } \\
\text { period }\end{array}$ & Yes & Yes \\
\hline Cambodia & Socio-Economic Survey & 2014 & ISCO codes ( 3 digits) & reported & monthly & Yes & Yes \\
\hline Indonesia & Labor Force Survey & 2015 & Country-specific, KJI, 3 digit & reported & $\begin{array}{l}\text { monthly and } \\
\text { hourly }\end{array}$ & Yes & No \\
\hline Pakistan & Labor Force Survey & 2014-2015 & $\begin{array}{l}\text { country-specific, PASCO, 4- } \\
\text { digits }\end{array}$ & reported & $\begin{array}{l}\text { Salary }+ \text { salary } \\
\text { period }\end{array}$ & Yes & Yes \\
\hline Mexico & Household Income Survey & 2016 & $\begin{array}{c}\text { Country-specific, SINCO, } 4 \\
\text { digits }\end{array}$ & reported & $\begin{array}{l}\text { Annual income \& } \\
\text { bi-annual income }\end{array}$ & Yes & Yes \\
\hline Bolivia & Household Income Survey & 2015 & $\begin{array}{c}\text { Country-specific, COB 2009, } \\
5 \text { digits }\end{array}$ & reported & $\begin{array}{l}\text { Salary }+ \text { salary } \\
\text { period }\end{array}$ & Yes & Yes \\
\hline
\end{tabular}


Table A2. Reports of in-kind payments

\begin{tabular}{|c|c|c|c|c|c|c|c|}
\hline Country & Source & Year & In-kind payment & $\begin{array}{c}\% \\
\text { teachers } \\
\text { reported } \\
\text { in-kind } \\
\text { payment }\end{array}$ & $\begin{array}{l}\text { Share of } \\
\text { in-kind } \\
\text { payment in } \\
\text { teacher } \\
\text { earnings }\end{array}$ & $\begin{array}{c}\% \text { others } \\
\text { reported } \\
\text { in-kind } \\
\text { payment }\end{array}$ & $\begin{array}{c}\text { Share of } \\
\text { in-kind } \\
\text { paymen } \\
\text { in total } \\
\text { earnings }\end{array}$ \\
\hline Burkina Faso & Continuous Multisectoral Survey & 2014 & Yes, benefits and nutrition & $0 \%$ & - & $0.1 \%$ & - \\
\hline Côte d'Ivoire & National Employment Survey & 2013 & No & - & - & - & - \\
\hline DR Congo & National Household Survey & 2012 & No & - & - & - & - \\
\hline The Gambia & Integrated Household Survey & 2010 & No & - & - & - & - \\
\hline Ghana & Ghana Living Standards Survey 6 & $2012-2013$ & Yes & $1.8 \%$ & $38.1 \%$ & $5.8 \%$ & $37.5 \%$ \\
\hline Liberia & Household Income and Expenditure Survey & 2014-2015 & Yes, payment in any other form & $8.8 \%$ & $31.7 \%$ & $24.6 \%$ & $19.5 \%$ \\
\hline Malawi & Integrated Household Panel Survey & 2010 & Yes, other allowance & $27.4 \%$ & $26.8 \%$ & $20.6 \%$ & $32.7 \%$ \\
\hline Namibia & Labor Force Survey & 2013 & $\begin{array}{c}\text { No, gross income before any } \\
\text { deduction }\end{array}$ & - & - & - & - \\
\hline Niger & $\begin{array}{l}\text { National Survey on Household Living } \\
\text { Conditions and Agriculture }\end{array}$ & 2014 & $\begin{array}{l}\text { Yes, in-kind }+ \text { nutrition } \\
\text { payment }\end{array}$ & $13.4 \%$ & $18.6 \%$ & $17.6 \%$ & $34.0 \%$ \\
\hline Nigeria & General Household Survey & 2015 & Yes, in-kind & $10.4 \%$ & $14.0 \%$ & $17.1 \%$ & $21.7 \%$ \\
\hline Senegal & Poverty Monitoring Survey & 2010 & $\begin{array}{l}\text { Reported total income including } \\
\text { in-kind payment }\end{array}$ & - & - & - & - \\
\hline Sierra Leone & Labor Force Survey & 2014 & Yes, in-kind + bonus & $9.5 \%$ & $15.3 \%$ & $40.1 \%$ & $27.1 \%$ \\
\hline Tanzania & Labor Force Survey & 2014 & No & & & - & - \\
\hline Uganda & Living Standards Measurement Survey & 2013 & Yes & $40.0 \%$ & $19.8 \%$ & $35.1 \%$ & $32.2 \%$ \\
\hline Zambia & Labor Force Survey & 2014 & Yes & $0.0 \%$ & - & $1.1 \%$ & - \\
\hline Cambodia & Socio-Economic Survey & 2014 & No & - & - & - & - \\
\hline Indonesia & Labor Force Survey & 2015 & Yes & $7.4 \%$ & - & $10.5 \%$ & $24.0 \%$ \\
\hline Pakistan & Labor Force Survey & 2014-2015 & Yes & $3.0 \%$ & $15.1 \%$ & $19.7 \%$ & $19.3 \%$ \\
\hline Mexico & Household Income Survey & 2016 & No & - & - & - & - \\
\hline Bolivia & Household Income Survey & 2015 & No & - & - & - & - \\
\hline
\end{tabular}


Table A3. Percent of workers receiving employee benefits

\begin{tabular}{|c|c|c|c|c|c|c|}
\hline & \multicolumn{2}{|c|}{ Paid leave } & \multicolumn{2}{|c|}{ Medical benefits } & \multicolumn{2}{|c|}{ Social security/Pension } \\
\hline & Teachers & $\begin{array}{c}\text { Other } \\
\text { workers }\end{array}$ & Teachers & $\begin{array}{c}\text { Other } \\
\text { workers }\end{array}$ & Teachers & $\begin{array}{c}\text { Other } \\
\text { workers }\end{array}$ \\
\hline \multicolumn{7}{|c|}{ African countries } \\
\hline Burkina Faso & 0.72 & 0.27 & 0.03 & 0.10 & 0.79 & 0.25 \\
\hline Côte d'Ivoire & 0.60 & 0.20 & 0.33 & 0.19 & - & - \\
\hline DR Congo & 0.10 & 0.10 & 0.02 & 0.07 & 0.04 & 0.09 \\
\hline The Gambia & 0.59 & 0.38 & - & - & 0.64 & 0.37 \\
\hline Ghana & 0.89 & 0.52 & 0.24 & 0.25 & 0.79 & 0.32 \\
\hline Liberia & - & - & 0.25 & 0.25 & - & - \\
\hline Malawi & - & - & - & - & - & - \\
\hline Namibia & 0.92 & 0.80 & 0.79 & 0.38 & 0.74 & 0.39 \\
\hline Niger & 0.77 & 0.37 & 0.37 & 0.22 & 0.48 & 0.27 \\
\hline Nigeria & - & - & 0.06 & 0.18 & 0.53 & 0.37 \\
\hline Senegal & - & - & 0.34 & 0.12 & 0.61 & 0.26 \\
\hline Sierra Leone & - & - & - & - & - & - \\
\hline Tanzania & 0.84 & 0.48 & - & - & 0.95 & 0.58 \\
\hline Uganda & 0.55 & 0.15 & 0.05 & 0.12 & 0.43 & 0.13 \\
\hline Zambia & 0.92 & 0.52 & 0.93 & 0.58 & 0.99 & 0.66 \\
\hline Average & 0.69 & 0.38 & 0.31 & 0.22 & 0.63 & 0.33 \\
\hline \multicolumn{7}{|c|}{ Comparator countries } \\
\hline Cambodia & - & - & - & - & - & - \\
\hline Indonesia & - & - & - & - & - & - \\
\hline Pakistan & 0.87 & 0.60 & 0.48 & 0.42 & - & - \\
\hline Bolivia & 0.89 & 0.36 & 0.87 & 0.33 & 0.93 & 0.38 \\
\hline Mexico & 0.88 & 0.79 & 0.92 & 0.90 & 0.75 & 0.67 \\
\hline Average & 0.88 & 0.58 & 0.76 & 0.55 & 0.84 & 0.53 \\
\hline
\end{tabular}

Notes: Sample includes all wage workers. “-” indicates that employee benefits are not reported in the corresponding country survey. Source: Surveys listed in Table 1. 
Table A4. Percent of teachers receiving employee benefits by contract type

\begin{tabular}{|c|c|c|c|c|c|c|}
\hline & $\begin{array}{l}\text { Pai } \\
\text { Permanent }\end{array}$ & $\begin{array}{l}\text { leave } \\
\text { Fixed term/ } \\
\text { temporary }\end{array}$ & $\begin{array}{l}\text { Medica } \\
\text { Permanent }\end{array}$ & $\begin{array}{l}\text { benefits } \\
\text { Fixed term/ } \\
\text { temporary }\end{array}$ & $\begin{array}{l}\text { Social sect } \\
\text { Permanent }\end{array}$ & $\begin{array}{l}\text { ty/Pension } \\
\text { Fixed term/ } \\
\text { temporary }\end{array}$ \\
\hline \multicolumn{7}{|c|}{ African countries } \\
\hline Burkina Faso & 0.84 & 0.35 & 0.03 & 0.06 & 0.84 & 0.35 \\
\hline Côte d'Ivoire & 0.69 & 0.45 & 0.42 & 0.16 & - & - \\
\hline DR Congo & 0.13 & 0.09 & 0.02 & 0.01 & 0.05 & 0.03 \\
\hline The Gambia & $*$ & $*$ & $*$ & $*$ & $*$ & $*$ \\
\hline Ghana & $*$ & $*$ & * & $*$ & $*$ & $*$ \\
\hline Liberia & $*$ & $*$ & $*$ & $*$ & $*$ & $*$ \\
\hline Malawi & $-*$ & -* & $-*$ & -* & $-*$ & $-*$ \\
\hline Namibia & 0.93 & 0.87 & 0.84 & 0.52 & 0.80 & 0.43 \\
\hline Niger & 0.81 & 0.68 & 0.42 & 0.24 & 0.61 & 0.15 \\
\hline Nigeria & $*$ & $*$ & $*$ & $*$ & $*$ & $*$ \\
\hline Senegal & - & - & 0.36 & 0.20 & 0.65 & 0.34 \\
\hline Sierra Leone & - & - & - & - & - & - \\
\hline Tanzania & 0.86 & 0.52 & - & - & 0.97 & 0.67 \\
\hline Uganda & 0.73 & 0.29 & 0.05 & 0.06 & 0.50 & 0.33 \\
\hline Zambia & 0.95 & 0.68 & 0.95 & 0.78 & 1.00 & 0.88 \\
\hline Average & 0.74 & 0.49 & 0.39 & 0.25 & 0.68 & 0.40 \\
\hline \multicolumn{7}{|c|}{ Comparator countries } \\
\hline Cambodia & -* & -* & -* & -* & -* & -* \\
\hline Indonesia & $-*$ & $-*$ & -* & -* & -* & -* \\
\hline Pakistan & 0.87 & 0.59 & 0.50 & 0.12 & - & - \\
\hline Bolivia & $*$ & $*$ & $*$ & $*$ & $*$ & $*$ \\
\hline Mexico & 0.94 & 0.79 & 0.97 & 0.64 & 0.82 & 0.38 \\
\hline Average & 0.91 & 0.69 & 0.74 & 0.38 & 0.82 & 0.38 \\
\hline
\end{tabular}

Notes: Sample includes all wage workers. “*” indicates that a country survey does not report a worker's contract type. “-” indicates that employee benefits are not reported in the corresponding country survey.

Source: Surveys listed in Table 1. 
Table A5. Percent of teachers who report receiving "fringe benefits" or "social benefits, allowances and/or bonuses"

Panel A: All grade 2 and grade 6 teachers

\begin{tabular}{|c|c|c|c|c|c|c|c|c|c|c|}
\hline & Benin & $\begin{array}{c}\text { Burkina } \\
\text { Faso }\end{array}$ & Burundi & Cameroun & $\begin{array}{c}\text { Congo } \\
\text { Rep. }\end{array}$ & $\begin{array}{c}\text { Côte } \\
\text { d'Ivoire }\end{array}$ & Niger & Senegal & Tchad & Togo \\
\hline \multicolumn{11}{|l|}{ Fringe benefits } \\
\hline Housing & 0.37 & 0.24 & 0.47 & 0.30 & 0.14 & 0.59 & 0.20 & 0.19 & 0.22 & 0.05 \\
\hline Catering & 0.01 & 0.06 & 0.00 & 0.04 & 0.06 & 0.05 & 0.02 & 0.06 & 0.02 & 0.01 \\
\hline Access to drinking water & 0.17 & 0.29 & 0.03 & 0.16 & 0.10 & 0.27 & 0.17 & 0.42 & 0.11 & 0.13 \\
\hline Transport & 0.07 & 0.01 & 0.22 & 0.03 & 0.39 & 0.21 & 0.12 & 0.04 & 0.20 & 0.02 \\
\hline \multicolumn{11}{|c|}{ Social benefits, allowances and/or bonuses } \\
\hline Health insurance & 0.03 & 0.03 & 0.11 & 0.01 & 0.01 & 0.11 & 0.03 & 0.11 & 0.01 & 0.43 \\
\hline Mutual health insurance & 0.02 & 0.00 & 0.87 & 0.00 & 0.06 & 0.53 & 0.01 & 0.53 & 0.01 & 0.01 \\
\hline Pension or annuity plan & 0.48 & 0.34 & 0.46 & 0.31 & 0.26 & 0.59 & 0.29 & 0.40 & 0.13 & 0.40 \\
\hline Housing allowance & 0.54 & 0.41 & 0.80 & 0.46 & 0.00 & 0.67 & 0.31 & 0.35 & 0.26 & 0.03 \\
\hline Supervised study allowance & 0.06 & 0.00 & 0.00 & 0.02 & 0.04 & 0.38 & 0.01 & 0.04 & 0.03 & 0.01 \\
\hline Examination allowance & 0.34 & 0.23 & 0.00 & 0.23 & 0.12 & 0.23 & 0.10 & 0.49 & 0.57 & 0.19 \\
\hline Teacher's bonus & 0.45 & 0.06 & 0.28 & 0.48 & 0.19 & 0.02 & 0.48 & 0.25 & 0.11 & 0.27 \\
\hline Back-to-school bonus & 0.66 & 0.01 & 0.01 & 0.03 & 0.00 & 0.00 & 0.01 & 0.00 & 0.01 & 0.46 \\
\hline Assignment grant & 0.10 & 0.03 & 0.00 & 0.02 & 0.12 & 0.00 & 0.06 & 0.05 & 0.10 & 0.01 \\
\hline Research allowance & 0.01 & 0.01 & 0.00 & 0.48 & 0.26 & 0.00 & 0.01 & 0.59 & 0.26 & 0.38 \\
\hline
\end{tabular}

Notes: Bold $>0.3$.

Source: PASEC 2014. 
Panel B: Grade 2 and grade 6 teachers: Civil servants only

\begin{tabular}{|c|c|c|c|c|c|c|c|c|c|c|}
\hline & Benin & $\begin{array}{c}\text { Burkina } \\
\text { Faso }\end{array}$ & Burundi & Cameroun & $\begin{array}{c}\text { Congo } \\
\text { Rep. }\end{array}$ & $\begin{array}{c}\text { Côte } \\
\text { d'Ivoire }\end{array}$ & Niger & Senegal & Tchad & Togo \\
\hline \multicolumn{11}{|l|}{ Fringe benefits } \\
\hline Housing & 0.59 & 0.17 & 0.46 & 0.39 & 0.18 & 0.72 & 0.44 & 0.37 & 0.72 & 0.04 \\
\hline Catering & 0.01 & 0.00 & 0.00 & 0.04 & 0.00 & 0.03 & 0.00 & 0.01 & 0.04 & 0.02 \\
\hline Access to drinking water & 0.15 & 0.25 & 0.03 & 0.23 & 0.07 & 0.32 & 0.20 & 0.28 & 0.23 & 0.11 \\
\hline Transport & 0.10 & 0.00 & 0.22 & 0.00 & 0.83 & 0.27 & 0.32 & 0.02 & 0.64 & 0.04 \\
\hline \multicolumn{11}{|c|}{ Social benefits, allowances and/or bonuses } \\
\hline Health insurance & 0.04 & 0.02 & 0.11 & 0.08 & 0.02 & 0.14 & 0.03 & 0.16 & 0.01 & 0.79 \\
\hline Mutual health insurance & 0.00 & 0.00 & 0.87 & 0.00 & 0.09 & 0.70 & 0.00 & 0.58 & 0.00 & 0.02 \\
\hline Pension or annuity plan & 0.76 & 0.60 & 0.47 & 0.65 & 0.62 & 0.77 & 0.57 & 0.80 & 0.38 & 0.65 \\
\hline Housing allowance & 0.90 & 0.71 & 0.80 & 0.85 & 0.00 & 0.88 & 0.83 & 0.93 & 0.86 & 0.03 \\
\hline Supervised study allowance & 0.03 & 0.00 & 0.00 & 0.04 & 0.02 & 0.51 & 0.02 & 0.01 & 0.08 & 0.02 \\
\hline Examination allowance & 0.50 & 0.43 & 0.00 & 0.53 & 0.03 & 0.29 & 0.08 & 0.74 & 0.81 & 0.33 \\
\hline Teacher's bonus & 0.67 & 0.14 & 0.28 & 0.89 & 0.38 & 0.02 & 0.69 & 0.60 & 0.36 & 0.50 \\
\hline Back-to-school bonus & 1.00 & 0.01 & 0.01 & 0.01 & 0.00 & 0.00 & 0.00 & 0.00 & 0.02 & 0.81 \\
\hline Assignment grant & 0.22 & 0.01 & 0.00 & 0.10 & 0.31 & 0.00 & 0.08 & 0.14 & 0.32 & 0.02 \\
\hline Research allowance & 0.02 & 0.00 & 0.00 & 0.85 & 0.75 & 0.00 & 0.00 & 0.84 & 0.86 & 0.63 \\
\hline
\end{tabular}

Notes: Bold $>0.3$

Source: PASEC 2014. 
Table A6. Median earnings of teachers by type

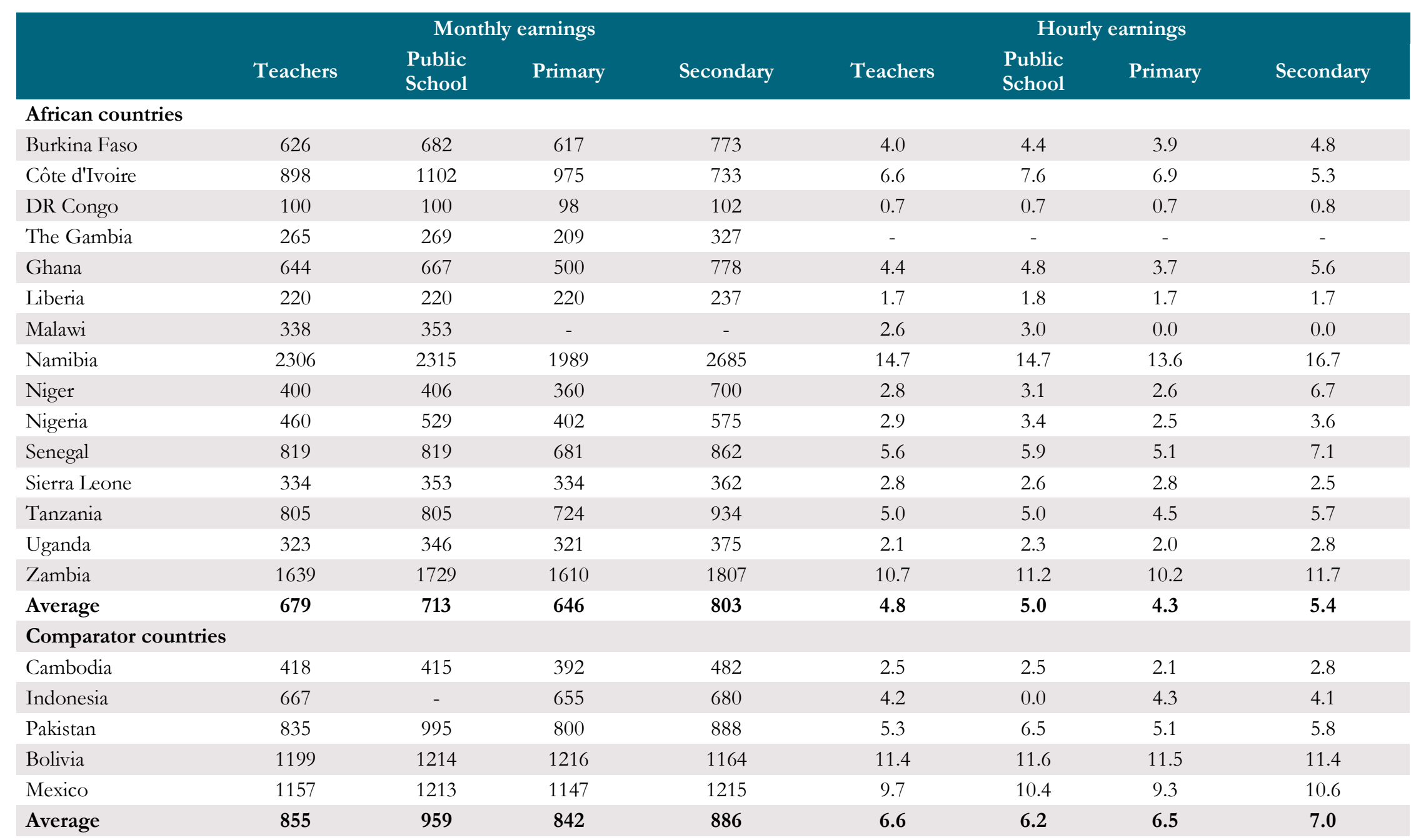

Notes: All the earnings are in PPP $(\$, 2011)$. Sample only include teachers with secondary or post-secondary education.

Source: Surveys listed in Table 1. 
Table A7. Monthly median earnings for workers with secondary school education by economic activity

\begin{tabular}{|c|c|c|c|c|c|c|c|c|c|c|}
\hline \multirow[b]{2}{*}{ Country } & \multirow[b]{2}{*}{ Teachers } & \multicolumn{9}{|c|}{ Other workers with secondary school education } \\
\hline & & Agriculture & Mining & Manufacturing & Construction & Retail & $\begin{array}{l}\text { Financial } \\
\text { services }\end{array}$ & $\begin{array}{l}\text { Admin } \\
\text { services }\end{array}$ & $\begin{array}{l}\text { Health and } \\
\text { social services }\end{array}$ & $\begin{array}{c}\text { Public } \\
\text { administration }\end{array}$ \\
\hline \multicolumn{11}{|c|}{ African countries } \\
\hline Burkina Faso & 580 & 209 & 186 & 232 & 232 & 162 & 492 & 255 & 278 & 320 \\
\hline Côte d'Ivoire & 975 & - & - & 322 & 627 & 237 & - & 477 & 763 & 297 \\
\hline DR Congo & 96 & 65 & 363 & 136 & 109 & 114 & 241 & 91 & 82 & 97 \\
\hline The Gambia & 254 & 204 & 210 & 179 & 270 & 189 & 408 & 194 & 240 & 236 \\
\hline Ghana & 278 & 278 & 500 & 228 & 444 & 222 & 278 & 278 & 364 & 667 \\
\hline Liberia & 211 & 255 & 370 & 171 & 278 & 143 & 417 & 222 & 226 & 185 \\
\hline Malawi & 294 & 176 & 338 & 191 & 206 & 147 & 559 & 287 & 221 & 268 \\
\hline Namibia & 1,447 & 334 & 1,085 & 506 & 506 & 362 & 1,356 & 362 & 687 & 1,085 \\
\hline Niger & 349 & 273 & 1,763 & 267 & 383 & 240 & 389 & 244 & 420 & 540 \\
\hline Nigeria & 230 & 207 & 589 & 402 & 460 & 155 & 195 & - & 270 & 352 \\
\hline Senegal & 688 & 431 & 791 & 431 & 388 & 302 & 735 & - & 485 & 647 \\
\hline Sierra Leone & 288 & 389 & 565 & 222 & 556 & 222 & 425 & 334 & 334 & 289 \\
\hline Tanzania & 724 & 402 & 1,073 & 547 & 580 & 560 & 668 & 410 & 672 & 731 \\
\hline Uganda & 188 & 148 & 987 & 178 & 237 & 158 & 99 & 420 & 271 & 346 \\
\hline Zambia & 1,610 & 215 & 1,073 & 394 & 429 & 286 & 1,594 & 286 & 1,073 & 1,252 \\
\hline Average & 547 & 256 & 707 & 294 & 380 & 233 & 561 & 297 & 426 & 487 \\
\hline \multicolumn{11}{|c|}{ Comparator countries } \\
\hline Cambodia & 401 & 334 & 412 & 386 & 445 & 371 & 742 & 386 & 341 & 430 \\
\hline Indonesia & 297 & 371 & 680 & 371 & 383 & 297 & 408 & 321 & 395 & 556 \\
\hline Pakistan & 748 & 355 & 640 & 426 & 426 & 355 & 592 & 391 & 536 & 800 \\
\hline Bolivia & 840 & 720 & 1,260 & 767 & 935 & 640 & 776 & 652 & 683 & 905 \\
\hline Mexico & 607 & 566 & 1,159 & 624 & 729 & 623 & 758 & 585 & 774 & 928 \\
\hline Average & 579 & 469 & 830 & 515 & 584 & 457 & 655 & 467 & 546 & 724 \\
\hline
\end{tabular}

Notes: All the earnings are in PPP (\$,2011). ISIC Rev.4 are used to classify economic activities (UNSD, 2007). Earnings in italic are estimated based on fewer than 10 observations. Sample only includes workers with secondary or post-secondary education.

Source: Surveys listed in Table 1. 
Table A8. Monthly median earnings for workers with post-secondary education by economic activity

\begin{tabular}{|c|c|c|c|c|c|c|c|c|c|c|}
\hline \multirow[b]{2}{*}{ Country } & \multirow[b]{2}{*}{ Teachers } & \multicolumn{9}{|c|}{ Other workers with post-secondary education } \\
\hline & & Agriculture & Mining & Manufacturing & Construction & Retail & $\begin{array}{l}\text { Financial } \\
\text { services }\end{array}$ & $\begin{array}{l}\text { Admin } \\
\text { services }\end{array}$ & $\begin{array}{c}\text { Health and } \\
\text { social services }\end{array}$ & $\begin{array}{c}\text { Public } \\
\text { administration }\end{array}$ \\
\hline \multicolumn{11}{|c|}{ African countries } \\
\hline Burkina Faso & 742 & 251 & 1,123 & 394 & 251 & 162 & 200 & 464 & 972 & 603 \\
\hline Côte d'Ivoire & 890 & 203 & 1,695 & 297 & 203 & 318 & 767 & 466 & 583 & 713 \\
\hline DR Congo & 109 & 172 & 452 & 167 & 608 & 163 & 376 & 330 & 109 & 136 \\
\hline The Gambia & 286 & 514 & - & 459 & 214 & 255 & 510 & - & 373 & 306 \\
\hline Ghana & 778 & 1,000 & 1,444 & 556 & 722 & 444 & 1,067 & 611 & 861 & 889 \\
\hline Liberia & 254 & 895 & 2,775 & 740 & 648 & 1,471 & 463 & 393 & 472 & 531 \\
\hline Malawi & 338 & 432 & 471 & 618 & 430 & 662 & 1,029 & 735 & 751 & 801 \\
\hline Namibia & 2,532 & 1,899 & 3,436 & 1,808 & 1,989 & 1,627 & 2,078 & 1,808 & 2,351 & 1,718 \\
\hline Niger & 682 & 1,511 & 3,111 & 3,511 & 1,422 & 893 & 1,111 & 578 & 1,244 & 1,244 \\
\hline Nigeria & 483 & 667 & 1,853 & 977 & 920 & 546 & 575 & - & 737 & 805 \\
\hline Senegal & 862 & 1,040 & 981 & 1,078 & 862 & 647 & 970 & - & 862 & 1,121 \\
\hline Sierra Leone & 362 & 2,948 & 541 & 311 & 222 & 528 & 667 & 434 & 378 & 834 \\
\hline Tanzania & 831 & 895 & 1,207 & 1,127 & 1,288 & 740 & 1,368 & 966 & 1,046 & 1,288 \\
\hline Uganda & 337 & 168 & 987 & 869 & 449 & 395 & 622 & 444 & 465 & 464 \\
\hline Zambia & 1,717 & 1,503 & 2,147 & 1,073 & 1,073 & 1,073 & 2,111 & 1,556 & 1,789 & 1,700 \\
\hline Average & 747 & 940 & 1,587 & 932 & 753 & 662 & 928 & 732 & 866 & 877 \\
\hline \multicolumn{11}{|c|}{ Comparator countries } \\
\hline Cambodia & 435 & 334 & 441 & 386 & 482 & 519 & 772 & 742 & 504 & 482 \\
\hline Indonesia & 692 & 655 & 1,137 & 741 & 778 & 531 & 741 & 680 & 618 & 791 \\
\hline Pakistan & 888 & - & 640 & 960 & 933 & 533 & 1,334 & 817 & 1,137 & 1,066 \\
\hline Bolivia & 1,203 & 1,187 & 2,229 & 1,063 & 1,062 & 709 & 1,308 & 1,145 & 1,304 & 1,308 \\
\hline Mexico & 1,177 & 933 & 1,707 & 1,128 & 1,167 & 851 & 1,127 & 798 & 1,264 & 1,215 \\
\hline Average & 879 & 777 & 1,231 & 856 & 884 & 629 & 1,056 & 836 & 965 & 972 \\
\hline
\end{tabular}

Notes: All the earnings are in PPP (\$,2011). ISIC Rev.4 are used to classify economic activities (UNSD, 2007). Earnings in italic are estimated based on fewer than 10 observations.

Sample only includes workers with secondary or post-secondary education.

Source: Surveys listed in Table 1. 
Table A9. Monthly earnings structure (R-squared)

\begin{tabular}{|c|c|c|c|c|}
\hline & & Teache & & \\
\hline & Teacher & $\begin{array}{r}\text { Primary } \\
\text { teacher }\end{array}$ & $\begin{array}{c}\text { Secondary } \\
\text { teacher }\end{array}$ & $\begin{array}{c}\text { Other wage } \\
\text { workers }\end{array}$ \\
\hline African coun & & & & \\
\hline Burkina Faso & 0.03 & 0.03 & 0.06 & 0.09 \\
\hline Côte d'Ivoire & 0.31 & 0.25 & 0.37 & 0.25 \\
\hline DR Congo & 0.13 & 0.12 & 0.25 & 0.18 \\
\hline The Gambia & 0.18 & 0.17 & 0.06 & 0.23 \\
\hline Ghana & 0.42 & 0.41 & 0.41 & 0.26 \\
\hline Liberia & 0.16 & 0.17 & 0.20 & 0.16 \\
\hline Malawi & 0.25 & - & - & 0.37 \\
\hline Namibia & 0.26 & 0.23 & 0.27 & 0.26 \\
\hline Niger & 0.28 & 0.23 & 0.60 & 0.41 \\
\hline Nigeria & 0.30 & 0.28 & 0.36 & 0.36 \\
\hline Senegal & 0.09 & 0.05 & 0.11 & 0.35 \\
\hline Sierra Leone & 0.14 & 0.11 & 0.25 & 0.11 \\
\hline Tanzania & 0.23 & 0.30 & 0.19 & 0.29 \\
\hline Uganda & 0.20 & 0.32 & 0.10 & 0.34 \\
\hline Zambia & 0.17 & 0.21 & 0.16 & 0.35 \\
\hline Average & 0.21 & 0.21 & 0.25 & 0.27 \\
\hline Comparator & & & & \\
\hline Cambodia & 0.12 & 0.06 & 0.12 & 0.14 \\
\hline Indonesia & 0.42 & 0.43 & 0.41 & 0.20 \\
\hline Pakistan & 0.48 & 0.51 & 0.50 & 0.37 \\
\hline Bolivia & 0.17 & 0.23 & 0.11 & 0.25 \\
\hline Mexico & 0.24 & 0.31 & 0.16 & 0.23 \\
\hline Average & 0.29 & 0.31 & 0.26 & 0.24 \\
\hline
\end{tabular}

Notes: Each cell reports the R-squared of the regression of $\ln$ (monthly earnings) on gender, age, agesquared, urbanicity and (a dummy for) post-secondary education for a specified occupation group. Sample includes wage workers with secondary or post-secondary education. Data are not available for Malawi's primary and secondary teachers.

Source: Surveys listed in Table 1. 
Table A10. Median regression estimates of monthly earning differentials

\begin{tabular}{|c|c|c|c|c|c|}
\hline & Teachers & Primary & Secondary & $\begin{array}{l}\text { Public } \\
\text { school }\end{array}$ & Public employees \\
\hline \multicolumn{6}{|c|}{ African countries } \\
\hline Burkina Faso & $\begin{array}{c}0.629 * * * \\
(0.088)\end{array}$ & $\begin{array}{c}0.635^{* * *} \\
(0.094)\end{array}$ & $\begin{array}{c}0.449 * * \\
(0.201)\end{array}$ & $\begin{array}{c}0.706^{* * *} \\
(0.094)\end{array}$ & $\begin{array}{c}0.456^{* * *} \\
(0.101)\end{array}$ \\
\hline Côte d'Ivoire & $\begin{array}{c}0.441 * * * \\
(0.119)\end{array}$ & $\begin{array}{c}0.486 * * * \\
(0.158)\end{array}$ & $\begin{array}{c}0.070 \\
(0.159)\end{array}$ & $\begin{array}{c}0.653 * * * \\
(0.137)\end{array}$ & $\begin{array}{c}0.306^{* * *} \\
(0.109)\end{array}$ \\
\hline DR Congo & $\begin{array}{c}-0.090 * * * \\
(0.027)\end{array}$ & $\begin{array}{c}-0.083^{* * *} \\
(0.029)\end{array}$ & $\begin{array}{c}-0.115^{* *} \\
(0.057)\end{array}$ & $\begin{array}{c}-0.092^{* * *} \\
(0.028)\end{array}$ & $\begin{array}{c}-0.029 * \\
(0.017)\end{array}$ \\
\hline The Gambia & $\begin{array}{c}-0.149 * * * \\
(0.050)\end{array}$ & $\begin{array}{c}-0.304^{* * *} \\
(0.059)\end{array}$ & $\begin{array}{c}0.060 \\
(0.070)\end{array}$ & $\begin{array}{c}-0.110^{*} \\
(0.058)\end{array}$ & $\begin{array}{l}-0.092 \\
(0.056)\end{array}$ \\
\hline Ghana & $\begin{array}{l}-0.023 \\
(0.045)\end{array}$ & $\begin{array}{l}-0.068 \\
(0.054)\end{array}$ & $\begin{array}{c}0.053 \\
(0.063)\end{array}$ & $\begin{array}{c}0.032 \\
(0.050)\end{array}$ & $\begin{array}{c}-0.142^{* * *} \\
(0.042)\end{array}$ \\
\hline Liberia & $\begin{array}{c}-0.281 \text { *** } \\
(0.080)\end{array}$ & $\begin{array}{c}-0.238^{* * *} \\
(0.089)\end{array}$ & $\begin{array}{c}-0.425^{* *} \\
(0.165)\end{array}$ & $\begin{array}{l}-0.154 \\
(0.096)\end{array}$ & $\begin{array}{l}-0.112 \\
(0.089)\end{array}$ \\
\hline Malawi & $\begin{array}{c}0.140^{* *} \\
(0.057)\end{array}$ & $\begin{array}{l}- \\
-\end{array}$ & - & $\begin{array}{c}0.228^{* * *} \\
(0.063)\end{array}$ & $\begin{array}{c}0.075 \\
(0.054)\end{array}$ \\
\hline Namibia & $\begin{array}{c}0.359 * * * \\
(0.071)\end{array}$ & $\begin{array}{c}0.354 * * * \\
(0.085)\end{array}$ & $\begin{array}{c}0.372^{* * *} \\
(0.108)\end{array}$ & $\begin{array}{c}0.373^{* * *} \\
(0.073)\end{array}$ & $\begin{array}{c}0.256^{* * *} \\
(0.056)\end{array}$ \\
\hline Niger & $\begin{array}{c}-0.168^{*} \\
(0.092)\end{array}$ & $\begin{array}{l}-0.064 \\
(0.103)\end{array}$ & $\begin{array}{c}-0.347^{* *} \\
(0.170)\end{array}$ & $\begin{array}{l}-0.033 \\
(0.098)\end{array}$ & $\begin{array}{c}-0.160^{* *} \\
(0.079)\end{array}$ \\
\hline Nigeria & $\begin{array}{c}-0.297 * * * \\
(0.072)\end{array}$ & $\begin{array}{c}-0.355^{* * *} \\
(0.081)\end{array}$ & $\begin{array}{l}-0.134 \\
(0.108)\end{array}$ & $\begin{array}{l}-0.068 \\
(0.077)\end{array}$ & $\begin{array}{l}-0.115 \\
(0.074)\end{array}$ \\
\hline Senegal & $\begin{array}{c}0.225^{* * *} \\
(0.058)\end{array}$ & $\begin{array}{c}0.266^{* * *} \\
(0.073)\end{array}$ & $\begin{array}{c}0.079 \\
(0.086)\end{array}$ & $\begin{array}{c}0.228^{* * *} \\
(0.060)\end{array}$ & $\begin{array}{c}0.059 \\
(0.050)\end{array}$ \\
\hline Sierra Leone & $\begin{array}{c}-0.201 * \\
(0.104)\end{array}$ & $\begin{array}{l}-0.203 \\
(0.128)\end{array}$ & $\begin{array}{l}-0.188 \\
(0.150)\end{array}$ & $\begin{array}{l}-0.153 \\
(0.113)\end{array}$ & $\begin{array}{l}-0.166 \\
(0.107)\end{array}$ \\
\hline Tanzania & $\begin{array}{c}-0.082^{* *} \\
(0.040)\end{array}$ & $\begin{array}{c}-0.105^{* *} \\
(0.046)\end{array}$ & $\begin{array}{l}-0.037 \\
(0.066)\end{array}$ & $\begin{array}{c}-0.075^{*} \\
(0.042)\end{array}$ & $\begin{array}{c}-0.184 * * * \\
(0.043)\end{array}$ \\
\hline Uganda & $\begin{array}{c}-0.304 * * * \\
(0.084)\end{array}$ & $\begin{array}{c}-0.350^{* * *} \\
(0.088)\end{array}$ & $\begin{array}{c}0.018 \\
(0.158)\end{array}$ & $\begin{array}{c}-0.270 * * * \\
(0.101)\end{array}$ & $\begin{array}{c}-0.505^{* * *} \\
(0.085)\end{array}$ \\
\hline Zambia & $\begin{array}{c}0.416^{* * *} \\
(0.059)\end{array}$ & $\begin{array}{c}0.425^{* * *} \\
(0.066)\end{array}$ & $\begin{array}{c}0.412^{* * *} \\
(0.099)\end{array}$ & $\begin{array}{c}0.458^{* * *} \\
(0.062)\end{array}$ & $\begin{array}{c}0.146^{* * *} \\
(0.034)\end{array}$ \\
\hline Comparator & & & & & \\
\hline Cambodia & $\begin{array}{c}-0.126 * * * \\
(0.027)\end{array}$ & $\begin{array}{c}-0.112^{* * *} \\
(0.028)\end{array}$ & $\begin{array}{l}-0.027 \\
(0.039)\end{array}$ & $\begin{array}{c}-0.117 * * * \\
(0.029)\end{array}$ & $\begin{array}{c}-0.044 * \\
(0.023)\end{array}$ \\
\hline Indonesia & $\begin{array}{c}-0.283 * * * \\
(0.009)\end{array}$ & $\begin{array}{c}-0.118^{* * *} \\
(0.010)\end{array}$ & $\begin{array}{c}-0.127 * * * \\
(0.013)\end{array}$ & $\begin{array}{l}- \\
-\end{array}$ & $\begin{array}{l}- \\
-\end{array}$ \\
\hline Pakistan & $\begin{array}{c}-0.198^{* * *} \\
(0.014)\end{array}$ & $\begin{array}{c}-0.098^{* * *} \\
(0.015)\end{array}$ & $\begin{array}{c}-0.067^{* * *} \\
(0.022)\end{array}$ & $\begin{array}{c}0.105^{* * *} \\
(0.016)\end{array}$ & $\begin{array}{c}0.049 * * * \\
(0.014)\end{array}$ \\
\hline Bolivia & $\begin{array}{c}0.024 \\
(0.030)\end{array}$ & $\begin{array}{c}0.021 \\
(0.033)\end{array}$ & $\begin{array}{l}-0.009 \\
(0.049)\end{array}$ & $\begin{array}{c}0.050 \\
(0.034)\end{array}$ & $\begin{array}{c}-0.138^{* * *} \\
(0.031)\end{array}$ \\
\hline Mexico & $\begin{array}{c}0.053^{* * *} \\
(0.018)\end{array}$ & $\begin{array}{c}0.085^{* * *} \\
(0.018)\end{array}$ & $\begin{array}{c}0.090 * * * \\
(0.031)\end{array}$ & $\begin{array}{c}0.117 * * * \\
(0.019)\end{array}$ & $\begin{array}{l}-0.008 \\
(0.020)\end{array}$ \\
\hline
\end{tabular}

Notes: Each column reports the coefficient in the median regressions of $\ln$ (monthly earnings) on (a dummy for) a type of teachers with controls. The comparison group are other wage workers. Controls include gender, age, age-squared, urbanicity and (a dummy for) post-secondary education. The last column reports the coefficients of teacher earnings premiums with the comparison group being other public sector employees. Standard errors in parentheses. ${ }^{* * *} \mathrm{p}<0.01,{ }^{* *} \mathrm{p}<0.05,{ }^{*} \mathrm{p}<0.1$.

Source: Surveys listed in Table 1. 
Table A11. Median regression estimates of hourly earning differentials

\begin{tabular}{|c|c|c|c|c|c|}
\hline & Teachers & Primary & Secondary & Public & Public employees \\
\hline \multicolumn{6}{|c|}{ African countries } \\
\hline Burkina Faso & $\begin{array}{c}0.764^{* * *} \\
(0.093)\end{array}$ & $\begin{array}{c}0.798^{* * *} \\
(0.097)\end{array}$ & $\begin{array}{c}0.539 * * * \\
(0.208)\end{array}$ & $\begin{array}{c}0.871 * * * \\
(0.099)\end{array}$ & $\begin{array}{c}0.648^{* * *} \\
(0.102)\end{array}$ \\
\hline Côte d'Ivoire & $\begin{array}{c}0.840 * * * \\
(0.135)\end{array}$ & $\begin{array}{c}0.872^{* * *} \\
(0.183)\end{array}$ & $\begin{array}{c}0.764 * * * \\
(0.188)\end{array}$ & $\begin{array}{c}1.042^{* * *} \\
(0.163)\end{array}$ & $\begin{array}{c}0.542^{* * *} \\
(0.138)\end{array}$ \\
\hline DR Congo & $\begin{array}{c}0.123^{* * *} \\
(0.037)\end{array}$ & $\begin{array}{c}0.119^{* * *} \\
(0.040)\end{array}$ & $\begin{array}{c}0.140 * \\
(0.078)\end{array}$ & $\begin{array}{c}0.098^{* *} \\
(0.039)\end{array}$ & $\begin{array}{c}0.101 \text { *** } \\
(0.035)\end{array}$ \\
\hline The Gambia & - & - & - & - & - \\
\hline Ghana & $\begin{array}{c}0.270^{* * *} \\
(0.053)\end{array}$ & $\begin{array}{c}0.246^{* * *} \\
(0.065)\end{array}$ & $\begin{array}{c}0.305^{* * *} \\
(0.074)\end{array}$ & $\begin{array}{c}0.314^{* * *} \\
(0.060)\end{array}$ & $\begin{array}{c}0.128 * * \\
(0.056)\end{array}$ \\
\hline Liberia & $\begin{array}{c}0.012 \\
(0.081)\end{array}$ & $\begin{array}{c}0.047 \\
(0.088)\end{array}$ & $\begin{array}{l}-0.041 \\
(0.162)\end{array}$ & $\begin{array}{c}0.121 \\
(0.096)\end{array}$ & $\begin{array}{c}0.218^{* *} \\
(0.088)\end{array}$ \\
\hline Malawi & $\begin{array}{c}0.190^{* * *} \\
(0.069)\end{array}$ & - & - & $\begin{array}{c}0.283^{* * *} \\
(0.075)\end{array}$ & $\begin{array}{c}0.168^{* *} \\
(0.073)\end{array}$ \\
\hline Namibia & $\begin{array}{c}0.527 * * * \\
(0.076)\end{array}$ & $\begin{array}{c}0.563^{* * *} \\
(0.090)\end{array}$ & $\begin{array}{c}0.467 * * * \\
(0.115)\end{array}$ & $\begin{array}{c}0.525^{* * *} \\
(0.079)\end{array}$ & $\begin{array}{c}0.449 * * * \\
(0.059)\end{array}$ \\
\hline Niger & $\begin{array}{c}0.081 \\
(0.098)\end{array}$ & $\begin{array}{c}0.133 \\
(0.108)\end{array}$ & $\begin{array}{l}-0.022 \\
(0.179)\end{array}$ & $\begin{array}{c}0.155 \\
(0.107)\end{array}$ & $\begin{array}{l}-0.046 \\
(0.093)\end{array}$ \\
\hline Nigeria & $\begin{array}{c}-0.208^{* * *} \\
(0.077)\end{array}$ & $\begin{array}{c}-0.246 * * * \\
(0.092)\end{array}$ & $\begin{array}{l}-0.075 \\
(0.122)\end{array}$ & $\begin{array}{c}0.016 \\
(0.080)\end{array}$ & $\begin{array}{l}-0.078 \\
(0.080)\end{array}$ \\
\hline Senegal & $\begin{array}{c}0.553^{* * *} \\
(0.065)\end{array}$ & $\begin{array}{c}0.585^{* * *} \\
(0.084)\end{array}$ & $\begin{array}{c}0.519 * * * \\
(0.099)\end{array}$ & $\begin{array}{c}0.608^{* * *} \\
(0.064)\end{array}$ & $\begin{array}{c}0.349 * * * \\
(0.058)\end{array}$ \\
\hline Sierra Leone & $\begin{array}{c}0.124 \\
(0.130)\end{array}$ & $\begin{array}{c}0.146 \\
(0.152)\end{array}$ & $\begin{array}{c}0.092 \\
(0.196)\end{array}$ & $\begin{array}{c}0.033 \\
(0.146)\end{array}$ & $\begin{array}{c}0.173 \\
(0.148)\end{array}$ \\
\hline Tanzania & $\begin{array}{c}0.034 \\
(0.050)\end{array}$ & $\begin{array}{c}0.021 \\
(0.057)\end{array}$ & $\begin{array}{c}0.035 \\
(0.082)\end{array}$ & $\begin{array}{c}0.048 \\
(0.052)\end{array}$ & $\begin{array}{c}-0.075^{*} \\
(0.043)\end{array}$ \\
\hline Uganda & $\begin{array}{c}-0.176^{*} \\
(0.100)\end{array}$ & $\begin{array}{c}-0.187^{*} \\
(0.105)\end{array}$ & $\begin{array}{c}0.287 \\
(0.188)\end{array}$ & $\begin{array}{l}-0.166 \\
(0.119)\end{array}$ & $\begin{array}{c}-0.394 * * * \\
(0.115)\end{array}$ \\
\hline Zambia & $\begin{array}{c}0.546^{* * *} \\
(0.065)\end{array}$ & $\begin{array}{c}0.532 * * * \\
(0.072)\end{array}$ & $\begin{array}{c}0.568 * * * \\
(0.108)\end{array}$ & $\begin{array}{c}0.585^{* * *} \\
(0.069)\end{array}$ & $\begin{array}{c}0.299 * * * \\
(0.040)\end{array}$ \\
\hline Comparator $\mathrm{c}$ & & & & & \\
\hline Cambodia & $\begin{array}{c}0.060 * * \\
(0.029)\end{array}$ & $\begin{array}{l}-0.034 \\
(0.037)\end{array}$ & $\begin{array}{c}0.130^{* * *} \\
(0.040)\end{array}$ & $\begin{array}{c}0.013 \\
(0.029)\end{array}$ & $\begin{array}{c}0.062 * * \\
(0.031)\end{array}$ \\
\hline Indonesia & $\begin{array}{c}-0.103 * * * \\
(0.009)\end{array}$ & $\begin{array}{c}0.009 \\
(0.012)\end{array}$ & $\begin{array}{c}-0.049 * * * \\
(0.014)\end{array}$ & $\begin{array}{l}- \\
-\end{array}$ & - \\
\hline Pakistan & $\begin{array}{c}0.006 \\
(0.016)\end{array}$ & $\begin{array}{c}0.082^{* * *} \\
(0.021)\end{array}$ & $\begin{array}{c}0.094 * * * \\
(0.027)\end{array}$ & $\begin{array}{c}0.280 * * * \\
(0.020)\end{array}$ & $\begin{array}{c}0.189 \text { *** } \\
(0.016)\end{array}$ \\
\hline Bolivia & $\begin{array}{c}0.525^{* * *} \\
(0.031)\end{array}$ & $\begin{array}{c}0.567 * * * \\
(0.045)\end{array}$ & $\begin{array}{c}0.548^{* * *} \\
(0.054)\end{array}$ & $\begin{array}{c}0.585^{* * *} \\
(0.037)\end{array}$ & $\begin{array}{c}0.383^{* * *} \\
(0.041)\end{array}$ \\
\hline Mexico & $\begin{array}{c}0.449 * * * \\
(0.018)\end{array}$ & $\begin{array}{c}0.455^{* * *} \\
(0.023)\end{array}$ & $\begin{array}{c}0.546^{* * *} \\
(0.033)\end{array}$ & $\begin{array}{c}0.536 * * * \\
(0.020)\end{array}$ & $\begin{array}{c}0.335^{* * *} \\
(0.022)\end{array}$ \\
\hline
\end{tabular}

Notes: Each column reports the coefficient in the median regressions of $\ln$ (monthly earnings) on (a dummy for) a type of teachers with controls. The comparison group are other wage workers. Controls include gender, age, age-squared, urbanicity and (a dummy for) post-secondary education. The last column reports the coefficients of teacher earnings premiums with the comparison group being other public sector employees. Standard errors in parentheses. ${ }^{* * *} \mathrm{p}<0.01,{ }^{* *} \mathrm{p}<0.05,{ }^{*} \mathrm{p}<0.1$.

Source: Surveys listed in Table 1. 
Table A12. Association between teacher salaries and student test scores

\begin{tabular}{|c|c|c|c|c|c|c|c|c|c|c|c|c|}
\hline & \multicolumn{2}{|c|}{ Grades 2 and 6} & \multicolumn{2}{|c|}{ Grade 2} & \multicolumn{2}{|c|}{ Grade 6} & \multicolumn{2}{|c|}{ Grades 2 and 6} & \multicolumn{2}{|c|}{ Grade 2} & \multicolumn{2}{|c|}{ Grade 6} \\
\hline & $\begin{array}{c}\text { Coef. } \\
\text { (1) }\end{array}$ & $\begin{array}{c}(\mathrm{SE}) \\
(2)\end{array}$ & $\begin{array}{c}\text { Coef. } \\
\text { (3) }\end{array}$ & $\begin{array}{c}(\mathrm{SE}) \\
(4)\end{array}$ & $\begin{array}{c}\text { Coef. } \\
\text { (5) }\end{array}$ & $\begin{array}{c}(\mathrm{SE}) \\
(6)\end{array}$ & $\begin{array}{c}\text { Coef. } \\
(7)\end{array}$ & $\begin{array}{c}(\mathrm{SE}) \\
(8)\end{array}$ & $\begin{array}{c}\text { Coef. } \\
(9)\end{array}$ & $\begin{array}{c}(\mathrm{SE}) \\
(10)\end{array}$ & $\begin{array}{c}\text { Coef. } \\
\text { (11) }\end{array}$ & $\begin{array}{c}(\mathrm{SE}) \\
(12)\end{array}$ \\
\hline All & $10.13^{* * *}$ & $(2.08)$ & $13.5^{* * *}$ & $(2.79)$ & $5.00^{* *}$ & $(2.52)$ & $5.91^{* * *}$ & $(2.22)$ & $8.11^{* * *}$ & $(3.08)$ & 3.43 & $(2.39)$ \\
\hline Benin & -1.43 & $(5.77)$ & $25.0^{* * *}$ & $(8.97)$ & $-15.0^{* *}$ & $(6.38)$ & $-19.5^{* * *}$ & $(6.09)$ & -19.6 & $(13.5)$ & $-16.5^{* *}$ & $(6.56)$ \\
\hline Burkina Faso & $24.6^{* * *}$ & $(6.71)$ & $24.9^{* * *}$ & $(7.87)$ & $24.0^{*}$ & $(12.7)$ & $30.4^{* *}$ & $(12.9)$ & 22.7 & $(19.0)$ & $41.4^{* *}$ & $(17.7)$ \\
\hline Burundi & -9.76 & $(7.44)$ & -14.9 & $(11.0)$ & 0.484 & $(4.53)$ & $-13.2^{*}$ & $(6.97)$ & $-21.7^{*}$ & $(11.7)$ & -2.68 & $(5.30)$ \\
\hline Cameroun & 6.98 & (5.31) & 12.4 & $(8.06)$ & -0.045 & $(7.19)$ & $10.9^{*}$ & $(5.67)$ & $17.9^{* *}$ & $(8.64)$ & 5.24 & (5.19) \\
\hline DR Congo & $9.33^{*}$ & $(5.33)$ & 5.22 & $(7.52)$ & $16.6^{* * *}$ & $(5.53)$ & 2.88 & $(3.29)$ & -3.35 & $(5.13)$ & $9.78^{* * *}$ & $(3.60)$ \\
\hline Côte d'Ivoire & $20.1 * * *$ & $(5.60)$ & $21.9^{* * *}$ & $(7.29)$ & $16.73^{* *} *$ & $(8.43)$ & $11.6^{*}$ & $(6.13)$ & $19.9 *$ & $(10.1)$ & 4.57 & $(6.72)$ \\
\hline Niger & 5.56 & $(4.56)$ & $24.4^{* *}$ & $(11.0)$ & -0.67 & $(3.81)$ & 3.36 & $(4.27)$ & $23.4^{*}$ & $(11.8)$ & 0.172 & $(3.55)$ \\
\hline Senegal & $18.1 * *$ & $(8.11)$ & 9.04 & $(11.6)$ & $35.0^{* * *}$ & $(7.14)$ & -5.76 & $(6.16)$ & -10.4 & $(7.58)$ & 7.15 & $(6.26)$ \\
\hline Tchad & 3.96 & $(5.50)$ & 5.17 & $(7.01)$ & 0.77 & $(7.70)$ & -0.669 & $(5.89)$ & 3.31 & $(7.04)$ & -0.682 & $(8.17)$ \\
\hline Togo & $14.4^{* * *}$ & $(3.73)$ & $18.2^{* * *}$ & $(5.13)$ & 7.75 & $(5.04)$ & $18.0^{* * *}$ & $(4.39)$ & $20.2^{* * *}$ & $(5.74)$ & $13.1^{* *}$ & $(6.27)$ \\
\hline Controls & \multicolumn{2}{|c|}{ No } & \multicolumn{2}{|c|}{ No } & \multicolumn{2}{|c|}{ No } & \multicolumn{2}{|c|}{ Yes } & \multicolumn{2}{|c|}{ Yes } & \multicolumn{2}{|c|}{ Yes } \\
\hline
\end{tabular}

Note: Table reports the coefficient on $\ln ($ salary) in regressions of test scores (averaged across reading and math) on ln(salary) without and with controls. Each coefficient/standard error pair is from a different regression. Controls are gender, experience and its square, years of schooling, highest education degree obtained, duration of preservice training, whether the teacher is also the principal, and contract status. Pooled model includes country fixed effects. Model groups across grades includes a dummy variable for grade 6 . Robust standard errors (clustered at the teacher level) are reported in parenthesis.

Source: PASEC 2014. 
Table A13. Correlations of teacher monthly earnings differential and structural factors

\begin{tabular}{lcc}
\hline & Monthly earnings differential & Hourly earnings differential \\
\hline GDP per capita & 0.1319 & -0.0031 \\
\hline \% wage workers in the labor force & $(0.5793)$ & $(0.9900)$ \\
\hline \% of women in other wage jobs & 0.692 & 0.3782 \\
& $(0.0007)$ & $-0.1001)$ \\
\hline Female labor participation rate & -0.6318 & $(0.6019)$ \\
& $(0.0028)$ & 0.1888 \\
Rate of teacher unionization & 0.2549 & $(0.7202)$ \\
& $(0.2782)$ & -0.1097 \\
Teacher/labor force ratio & 0.3666 & $(0.6453)$ \\
\hline Average annual change in teacher/labor & $(0.4747)$ & 0.1999 \\
force ratio & 0.0487 & $(0.4118)$ \\
\hline
\end{tabular}

Notes: P-values in parentheses. Source: Surveys listed in Table 1. Teacher/labor force ratio and average annual change in teacher/labor force ratio are from PASEC (2014). 